\title{
Resolving the timescales of magmatic and hydrothermal processes associated with porphyry deposit formation using zircon $\mathrm{U}-\mathrm{Pb}$ petrochronology
}

\author{
Simon J. E. Large ${ }^{1, a}$, Jörn-Frederik Wotzlaw ${ }^{1}$, Marcel Guillong ${ }^{1}$, Albrecht von Quadt ${ }^{1}$, and Christoph A. Heinrich ${ }^{1,2}$ \\ ${ }^{1}$ Department of Earth Sciences, Eidgenössische Technische Hochschule (ETH) Zurich, 8092 Zürich, Switzerland \\ ${ }^{2}$ Faculty of Mathematics and Natural Sciences, University of Zurich, 8006 Zürich, Switzerland \\ ${ }^{a}$ current address: Department of Earth Sciences, Natural History Museum, Cromwell Road, London, SW7 5BD, UK
}

Correspondence: Simon J. E. Large (s.large@nhm.ac.uk)

Received: 7 February 2020 - Discussion started: 25 February 2020

Revised: 19 June 2020 - Accepted: 1 July 2020 - Published: 31 July 2020

\begin{abstract}
Understanding the formation of economically important porphyry $\mathrm{Cu}-\mathrm{Au}$ deposits requires knowledge of the magmatic-to-hydrothermal processes that act within the much larger magmatic system and the timescales on which they occur. We apply high-precision zircon geochronology (chemical abrasion-isotope dilution-thermal ionisation mass spectrometry; CA-ID-TIMS) and spatially resolved zircon geochemistry (laser ablation inductively coupled plasma mass spectrometry; LA-ICP-MS) to constrain the magmatic evolution of the underlying magma reservoir at the Pliocene Batu Hijau porphyry $\mathrm{Cu}-\mathrm{Au}$ deposit. We then use this extensive dataset to assess the accuracy and precision of different $\mathrm{U}-\mathrm{Pb}$ dating methods of the same zircon crystals.

Emplacement of the oldest pre- to syn-ore tonalite $(3.736 \pm 0.023 \mathrm{Ma})$ and the youngest tonalite porphyry to cross-cut economic $\mathrm{Cu}-\mathrm{Au}$ mineralisation $(3.646 \pm$ $0.022 \mathrm{Ma}$ ) is determined by the youngest zircon grain from each sample, which constrains the duration of metal precipitation to fewer than $90 \pm 32 \mathrm{kyr}$. Overlapping spectra of single zircon crystallisation ages and their trace element distributions from the pre-, syn and post-ore tonalite porphyries reveal protracted zircon crystallisation together with apatite and plagioclase within the same magma reservoir over $>$ 300 kyr. The presented petrochronological data constrain a protracted early $>200 \mathrm{kyr}$ interval of melt differentiation and cooling within a large heterogeneous magma reservoir, followed by magma storage in a highly crystalline state and chemical and thermal stability over several tens of thousands of years during which fluid expulsion formed the ore deposit.
\end{abstract}

Irregular trace element systematics suggest magma recharge or underplating during this final short time interval.

The comparison of high-precision CA-ID-TIMS results with in situ LA-ICP-MS and a sensitive high-resolution ion microprobe (SHRIMP) U-Pb geochronology data from the same zircon grains allows a comparison of the applicability of each technique as a tool to constrain dates and rates on different geological timescales. All techniques provide accurate dates but with different precision. Highly precise dates derived by the calculation of the weighted mean and standard error of the mean of the zircon dates obtained by in situ techniques can lead to ages of unclear geological significance that are older than the maximum ages of emplacement given by the CA-ID-TIMS ages of the youngest zircons in each sample. This lack of accuracy of the weighted means is due to the protracted nature of zircon crystallisation in upper crustal magma reservoirs, suggesting that standard errors should not be used as a means to describe the uncertainty in those circumstances. We conclude from this and similar published studies that the succession of magma and fluid pulses forming a single porphyry deposit and similarly rapid geological events are too fast to be reliably resolved by in situ $\mathrm{U}-\mathrm{Pb}$ geochronology and that assessing the tempo of ore formation requires CA-ID-TIMS geochronology. 


\section{Introduction}

Zircon geochronology is widely applied to date geological events and constrain timescales of geological processes. Combined with zircon geochemistry it has improved our understanding of crustal magmatic systems, such as those forming economically important magmatic-hydrothermal porphyry $\mathrm{Cu}-\mathrm{Au}$ deposits. Advances in analytical techniques resulted in a shift from establishing the ages of magma emplacement or crystallisation to resolving the durations of magmatic and associated hydrothermal processes, such as magma accumulation or recharge, fractional crystallisation, or hydrothermal ore formation, and it has resulted in unprecedented information about the mechanisms and scales of magma ascent and storage in the earth's crust (e.g. Vazquez and Reid, 2004; Chamberlain et al., 2014; Barboni et al., 2016; Bucholz et al., 2017).

Porphyry copper deposits provide successively quenched samples of magma extracted from large crustal-scale hydrous magma systems. They are therefore a critical source of information about the processes and rates of magma ascent, magma storage and fluid generation, bridging those of volcanism and pluton formation. The identification of the processes that lead to porphyry deposit formation (e.g. Rohrlach et al., 2005; Audétat et al., 2008; Richards, 2013; Wilkinson, 2013) and the timescales on which they operate can provide us with valuable information about arc magmatic processes but could also potentially help in discriminating possibly fertile magmatic systems from ubiquitous infertile systems resulting in barren intrusions or volcanic eruptions.

Porphyry $\mathrm{Cu}-\mathrm{Au}$ deposits commonly display clear field relationships of successive generations of porphyritic stocks or dikes, which were injected into sub-volcanic and other upper-crustal rock sequences (Sillitoe, 2010). The injected porphyry magmas thus provide snapshots of the underlying, vertically and laterally extensive magma reservoirs (e.g. Dilles, 1987; Steinberger et al., 2013). Cross-cutting relationships between veins and intrusive rocks suggest temporal overlap of hydrothermal alteration, ore mineralisation and porphyry emplacement (Proffett, 2003; Seedorff and Einaudi, 2004; Redmond and Einaudi, 2010). Strong hydrothermal alteration of the intrusive rocks associated with ore formation severely disturbs the geochemical information of most minerals and whole-rock compositions. While providing important insights into the hydrothermal history of a deposit (e.g. Roedder, 1971; Dilles and Einaudi, 1992; Landtwing et al., 2005; Cathles and Shannon, 2007; Seedorff et al., 2008; Large et al., 2016), it limits the investigation of the magma evolution, especially for the porphyries that are most intimately associated with ore formation. Zircon is a widespread mineral in intermediate to felsic rocks that is resistant to nearly all hydrothermal alteration and can thus provide coherent information about the evolution of a magmatic system.
Recent advances in high-precision zircon geochronology by chemical abrasion-isotope dilution-thermal ionisation mass spectrometry (CA-ID-TIMS; e.g. Mattinson, 2005; Bowring et al., 2011; McLean et al., 2011a, 2015; Condon et al., 2015) now allow dating of the porphyritic intrusions associated with ore formation with unprecedented precision. The dramatically improved precision permits the constraint of rapid events, such as individual porphyry emplacement and hydrothermal mineralisation phases $(<100 \mathrm{kyr}$; von Quadt et al., 2011; Buret et al., 2016; Tapster et al., 2016), that typically occur at the end of a longer-term period of volcanism and intrusive magma emplacement extending over several million years (e.g. Deino and Keith, 1997; Halter et al., 2004; Maksaev et al., 2004; Rohrlach et al., 2005; Lee et al., 2017). The integration of the temporal and chemical information gained from zircon is referred to as zircon petrochronology and can yield time-calibrated information about magma chemistry, thermal evolution and crystallinity during zircon crystallisation in magmatic systems (e.g Schoene et al., 2012; Chelle-Michou et al., 2014; Samperton et al., 2015; Buret et al., 2016; Szymanowski et al., 2017).

Timescales for magmatic and hydrothermal processes involved in porphyry ore formation have been suggested based on in situ U-Pb data (e.g. Garwin, 2000; Banik et al., 2017; Lee et al., 2017) and CA-ID-TIMS geochronology, which became increasingly precise (e.g. von Quadt et al., 2011; Chelle-Michou et al., 2014; Buret et al., 2016; Tapster et al., 2016; Gilmer et al., 2017; Large et al., 2018). However, several studies applying multiple techniques to the same sample sets have resulted in differing dates (von Quadt et al., 2011; Chiaradia et al., 2013, 2014; Chelle-Michou et al., 2014; Correa et al., 2016). The discrepancy demands a more detailed understanding of the precision and accuracy of the techniques and statistical data treatment that are applied to derive a geological age. This is not only fundamental for resolving dates and rates of geological processes in ore deposit research but provides more general insights into the geological meaning of magmatic dates and rates obtained by $\mathrm{U}-\mathrm{Pb}$ geochronology.

For the present paper, we obtained a large dataset of zircon geochemistry and geochronology by laser ablation inductively coupled plasma mass spectrometry (LAICP-MS) followed by high-precision geochronology of the same zircon crystals, utilising chemical abrasion-isotope dilution-thermal ionisation mass spectrometry (CA-IDTIMS). These coupled data from the world-class Batu Hijau porphyry $\mathrm{Cu}-\mathrm{Au}$ deposit allow us to resolve the chemical evolution and the changing physical state of the magma reservoir over time as well as the timescales of hydrothermal processes. In addition, previously published data on the same lithologies permit a critical comparison of two in situ microanalytical methods (sensitive high-resolution ion microprobe, SHRIMP, data by Garwin, 2000), LA-ICPMS presented here) with high-precision U-Pb CA-ID-TIMS geochronology (this study). This allows us to critically com- 
pare the effects of variable degrees of precision and of the statistical treatment of data on the resulting interpreted ages, and it provides a means to test the accuracy of the different techniques.

\section{Geological background}

The Pliocene island-arc-hosted world-class porphyry deposit of Batu Hijau is located on the island of Sumbawa, Indonesia (Fig. 1), and it is one of the largest $\mathrm{Cu}$ and Au resources in the south-west Pacific region (7.23 Mt Cu and 572 $\mathrm{t} \mathrm{Au}$; Cooke et al., 2005). It is currently the only mined porphyry deposit in the Sunda-Banda volcanic arc, where $\mathrm{Cu}-\mathrm{Au}$ porphyries are restricted to a narrow segment of the eastern Sunda-Banda arc from 115 and $120^{\circ} \mathrm{E}$ (Fig. 1), where the Australian plate has been being subducted since the Eocene (Hall, 2002).

The exposed islands of the Sunda-Banda arc are characterised by late Oligocene to early Miocene calc-alkaline basaltic to andesitic arc rocks that are overlain or intruded by a late Miocene to Pleistocene calc-alkaline volcanic and plutonic rock suite ranging from basaltic to rhyolitic compositions (Hamilton, 1979; Hutchison, 1989). The magmatic arc hosts a variety of ore deposit types, including porphyry $\mathrm{Cu}-$ Au deposits; high-, intermediate- and low-sulfidation epithermal deposits; and a volcanic-hosted massive sulfide (VMS) deposit on Wetar (Fig. 1).

The geology of the island of Sumbawa, hosting the Batu Hijau deposit, is dominated by early Miocene to Holocene volcanic arc successions deposited on oceanic crust that is 14-23 km thick (Hamilton, 1979; Barberi et al., 1987). Thickened continental crust observed in most other porphyry-mineralised magmatic arcs and commonly considered a prerequisite for porphyry $\mathrm{Cu}$ formation (Rohrlach et al., 2005; Chiaradia, 2015; Lee and Tang, 2020) is lacking beneath Sumbawa (Garwin et al., 2005). The distribution of volcano-sedimentary units, intrusions and the current coastline of Sumbawa are controlled by a major arc-transverse, left-lateral oblique-slip fault zone (Arif and Baker, 2004; Garwin et al., 2005). The fault zone strikes south-south-west to north-north-east about $30 \mathrm{~km}$ east of the Batu Hijau deposit, coinciding with the north-easterly projection of the Roo Rise oceanic plateau (Fig. 1).

The hypabyssal stocks in the Batu Hijau district are intruded into an early to middle Miocene volcano-sedimentary rock sequence $(<21$ Ma based on biostratigraphy; Adams, 1984; Berggren et al., 1995) that reaches a thicknesses of up to $1500 \mathrm{~m}$ in south-western Sumbawa. The low- $\mathrm{K}_{2} \mathrm{O}$, calcalkaline, sub-volcanic intrusive rocks in the Batu Hijau district have andesitic to quartz-dioritic and tonalitic compositions (Foden and Varne, 1980; Garwin, 2000) and were emplaced in several pulses during the late Miocene and Pliocene (Garwin, 2000). Over this multi-million-year magmatic history, a continuous geochemical evolution towards more fractionated lithologies is indicated by whole-rock chemistry and
Fe-isotopic evidence of the magmatic rock suite in the Batu Hijau district (Garwin, 2000; Wawryk and Foden, 2017). Within the Batu Hijau deposit, andesite porphyries and different quartz diorite bodies are the earliest recognised stocks, whereas three tonalite porphyries are the youngest exposed intrusions (Clode, 1999). These tonalite porphyries, which are associated with economically important $\mathrm{Cu}-\mathrm{Au}$ mineralisation and pervasive hydrothermal alteration at Batu Hijau, were emplaced as narrow, semi-cylindrical stocks into a broad east-north-east trending structural dome between $\sim 3.9$ and 3.7 Ma (Fig. 2; Garwin, 2000). Based on petrography and cross-cutting relationships, they were termed old tonalite, intermediate tonalite and young tonalite (Fig. 3; Meldrum et al., 1994; Clode, 1999; Setynadhaka et al., 2008).

All three tonalite intrusions are petrographically similar and are geochemically described as low-K calc-alkaline tonalites (Idrus et al., 2007). The least altered specimens contain phenocrysts of plagioclase, hornblende, quartz, biotite and magnetite with or without ilmenite hosted in an aplitic groundmass of plagioclase and quartz (Fig. 3; Mitchell et al., 1998; Clode, 1999; Garwin, 2000; Idrus et al., 2007). Notably, all three porphyry intrusions lack potassium feldspar. Identified accessory minerals include apatite, zircon and rare titanites. Relicts of clinopyroxene can be identified within the tonalites. Vein density, ore grade and alteration intensity decrease from the old to young tonalite. The old tonalite is the volumetrically smallest, occurring mostly at the edges of the composite stock. It can clearly be identified in drill core, where its veins are truncated by later intrusions (Fig. 3), but it is currently not separated from the intermediate ionalite by the mine geology department at Batu Hijau because their phenocryst proportion is almost indistinguishable (Fig. 2). It locally contains the highest ore grades $(>1 \% \mathrm{Cu}$ and $>1 \mathrm{~g} \mathrm{t}^{-1} \mathrm{Au}$ ), and its matrix is characteristically the coarsest of the three tonalite intrusions. The intermediate tonalite is the volumetrically largest of the three porphyry intrusions and is strongly mineralised (Fig. 2). The intermediate tonalite is porphyritic with phenocrysts, including characteristic euhedral quartz phenocrysts, which are $<8 \mathrm{~mm}$ in diameter (Fig. 3b). The young tonalite is the youngest intrusive rock, and it cuts most vein generations, ore mineralisation and alteration (Fig. 3c, e). It is strongly porphyritic with the largest-observed phenocrysts, including euhedral quartz phenocrysts, and contains elevated but subeconomic metal grades $\left(<0.3 \% \mathrm{Cu}\right.$ and $\left.<0.5 \mathrm{~g} \mathrm{t}^{-1} \mathrm{Au}\right)$.

Copper and gold are systematically zoned within the deposit. High-Au zones are tightly enveloped around the tonalite stocks, whereas high copper grades extend further out into the volcanic lithic breccia and the equigranular quartz diorite (Fig. 2). The lowest $\mathrm{Cu} / \mathrm{Au}$ ratios occur towards and below the current pit floor, and higher $\mathrm{Cu} / \mathrm{Au}$ ratios are recorded peripheral to the central porphyry stock and towards the upper, already-mined part of the ore body. A positive correlation between vein density and $\mathrm{Cu}$ and $\mathrm{Au}$ 


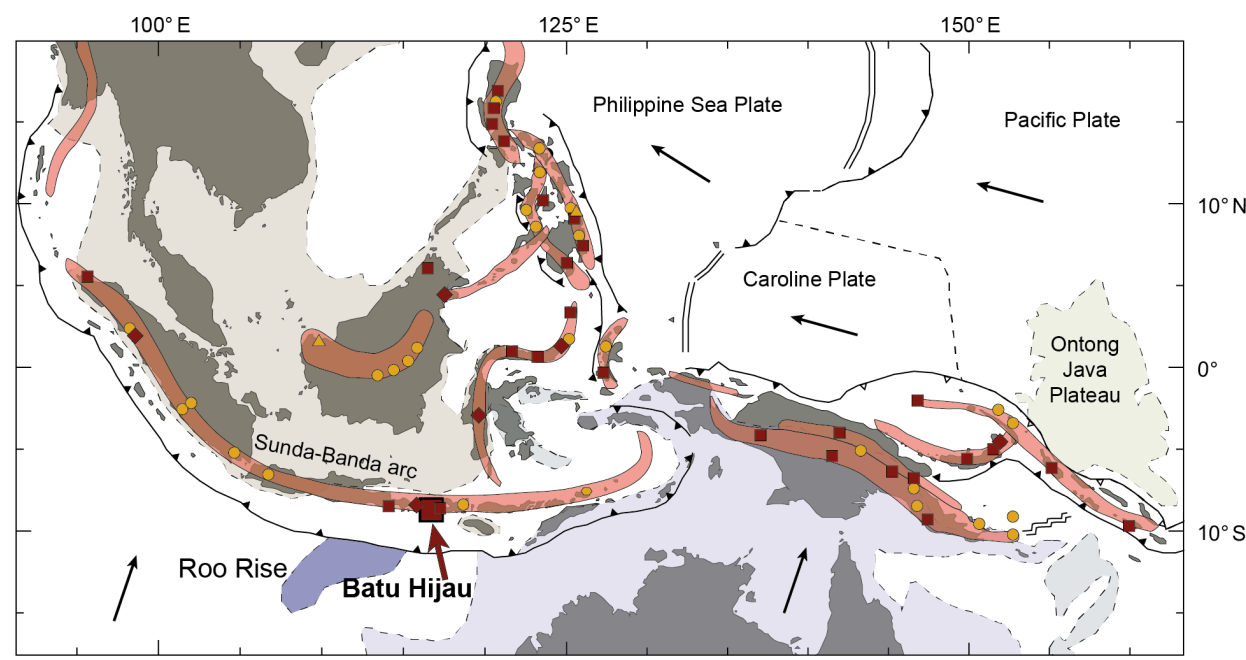

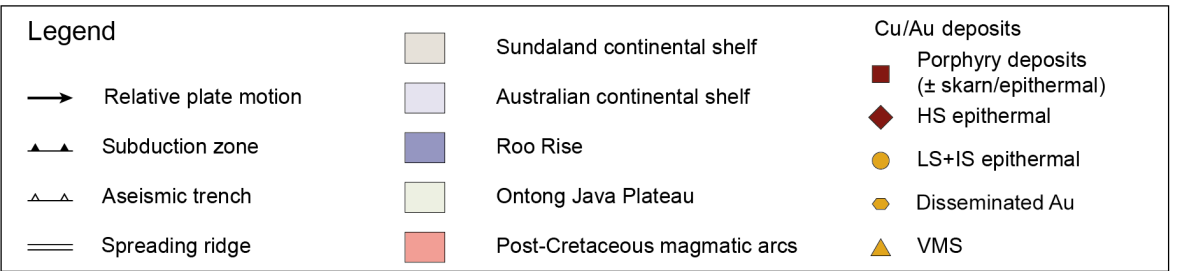

Figure 1. Tectonic map of South East Asia and the south-west Pacific. The Batu Hijau porphyry Cu-Au deposit (enlarged red square) is located on Sumbawa on the subduction-related magmatic Sunda-Banda arc within a small corridor between 110 and $120^{\circ} \mathrm{E}$ that hosts several porphyry deposits. Arrows display plate motion relative to the Eurasian plate (Sundaland shield) but do not indicate velocity. HS: high sulfidation; IS: intermediate sulfidation; LS: intermediate sulfidation; VMS: volcanic hosted massive sulfide deposit. Most deposit locations are from Garwin et al. (2005).

contents was described at Batu Hijau (Mitchell et al., 1998; Clode, 1999; Arif and Baker, 2004). A veins were suggested to comprise $\sim 80 \%$ of all quartz veins and contain a similar fraction of $\mathrm{Cu}$ (Mitchell et al., 1998). Most earlier authors suggested that the bulk of $\mathrm{Cu}$ and $\mathrm{Au}$ was precipitated as bornite during early $\mathrm{A}$ vein formation and converted to later chalcopyrite and gold associated with $\mathrm{AB}$ and $\mathrm{B}$ vein formation (Clode, 1999; Arif and Baker, 2004; Proffett, 2009). More recent studies on vein relationships and mineralogy using scanning electron microscopy cathodoluminescence (SEM-CL) petrography combined with fluid inclusion analyses suggest that $\mathrm{Cu}-\mathrm{Au}$ ore mineralisation including bornite, chalcopyrite and gold all precipitated with a late quartz generation post-dating high-temperature $\mathrm{A}$ and $A B$ vein quartz at a lower temperature together with the formation of brittle fractures associated with thin chlorite, white mica halos ( $\sim$ C veins and "paint veins"; Zwyer, 2011; Schirra et al., 2019). Irrespective of the debated timing of stockwork quartz veins and economic ore metal introduction in the old and intermediate tonalites, the young tonalite cuts through all high-grade $\mathrm{Cu}$ and $\mathrm{Au}$ zones, demonstrating its late, largely post-mineralisation emplacement (Figs. 2, 3e). Therefore, the maximum duration of economic mineralisation is bracketed by the emplacement ages of the $\mathrm{Cu}-\mathrm{Au}$-rich old tonalite predating it and the young tonalite post-dating it.

\section{Materials and methods}

Based on detailed core logging and outcrop mapping with company geologists in May 2016, one sample each from the old tonalite, intermediate tonalite, young tonalite and equigranular quartz diorite was selected from locations where the lithologies were in unequivocal relative time relationship (cross-cutting relationship; Fig. 3; see Supplement for sample locations). Rocks were crushed and zircons separated with conventional techniques, including Selfrag ${ }^{\mathrm{TM}}$ disintegration, panning and heavy liquid mineral separation (methylene iodide; $3.3 \mathrm{~g} \mathrm{~cm}^{-3}$ ). Selected zircons were annealed for $48 \mathrm{~h}$ at $900^{\circ} \mathrm{C}$, mounted in epoxy resin and polished to reveal their crystal interior. Polished zircons were carbon-coated and imaged using SEM-CL (Tescan EOscan VEGA XLSeries 4 scanning electron microscope) prior to in situ LA-ICP-MS analysis for trace elements and U-Pb isotopes, employing a $193 \mathrm{~nm}$ ASI RESOlution (S155) ArF excimer laser with a $30 \mu \mathrm{m}$ spot diameter, $5 \mathrm{~Hz}$ repetition rate and $2 \mathrm{~J} \mathrm{~cm}^{-2}$ energy density coupled to an element SF-ICPMS. A detailed description of the method including data reduction and results on secondary reference materials can be found in Guillong et al. (2014) and the Supplement. Generally, at least one spot was chosen in the interior (core) and one on the exterior (rim) part of the zircon, but up to four individ- 
(a)

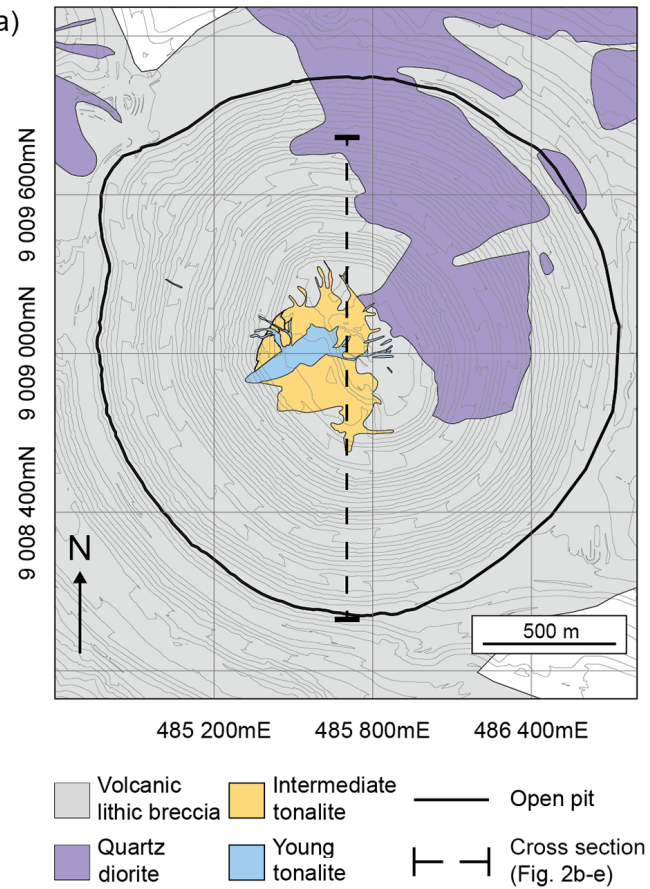

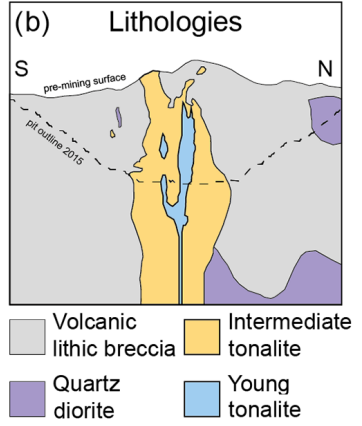

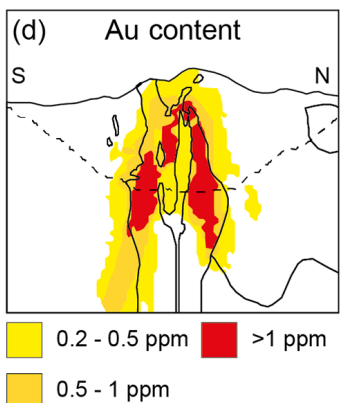

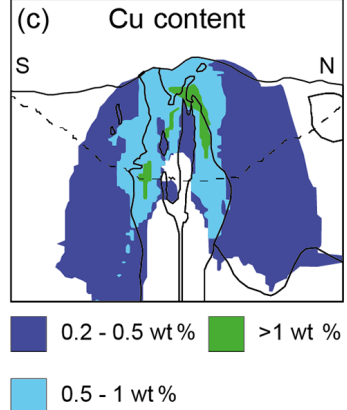

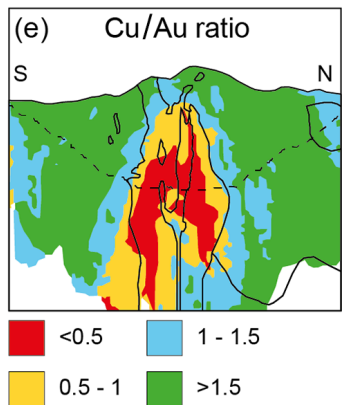

Figure 2. Geological map (a) and north-to-south cross-sections with lithological information and grade contours (b-e) of the open pit at Batu Hijau. The intermediate and young tonalite intruded into a volcanic lithic breccia and the equigranular quartz diorite (a, b). Note that the extent of the old tonalite is not displayed but is included in the intermediate tonalite. The dashed line in panel (a) is the N-S section displayed in (b)-(e). Thin grey lines in panel (a) indicate mine benches. $\mathrm{Cu}$ and $\mathrm{Au}$ grades (c, d) are enveloped around the tonalites and a deep, central barren core. High-grade $\mathrm{Cu}$ and $\mathrm{Au}$ mineralisation is cut by the young tonalite. The ratios of $\mathrm{Cu}$ to $\mathrm{Au}(\mathrm{e})$ illustrate strong $\mathrm{Au}$ enrichment proximal to the intermediate tonalite and $\mathrm{Cu}$-dominated distal mineralisation. Map, section and grades are based on company information from May 2016.

ual spots were analysed per zircon (Fig. 3f) to obtain in situ geochemical information and $\mathrm{U}-\mathrm{Pb}$ dates. All ${ }^{206} \mathrm{~Pb} /{ }^{238} \mathrm{U}$ dates were corrected for initial ${ }^{230} \mathrm{Th}-{ }^{238} \mathrm{U}$ disequilibrium in the ${ }^{238} \mathrm{U}-{ }^{206} \mathrm{~Pb}$ decay chain (e.g. Schärer, 1984). Ratios of $\mathrm{Th} / \mathrm{U}$ recorded by zircons cluster around $0.3-0.6$, and the dates were therefore corrected assuming a constant $\mathrm{Th} / \mathrm{U}_{\text {melt }}$ of 2 based on partition coefficients $(0.25)$ by Rubatto and Hermann (2007). Variation in the assumed $\mathrm{Th} / \mathrm{U}_{\text {melt }}$ by \pm 0.5 would result in changes in individual ${ }^{238} \mathrm{U}-{ }^{206} \mathrm{~Pb}$ dates of $<10 \mathrm{kyr}$, far below analytical uncertainty.

Titanium concentrations in zircon have been calibrated as a proxy for the crystallisation temperature of zircons (Watson and Harrison, 2005; Watson et al., 2006; Ferry and Watson, 2007) and have been widely used in igneous and ore deposit petrology (e.g. Claiborne et al., 2010b; Reid et al., 2011; Chelle-Michou et al., 2014; Dilles et al., 2015; Buret et al., 2016; Lee et al., 2017). The determination of accurate zircon crystallisation temperatures by Ti-in-zircon thermometry (Ferry and Watson, 2007) requires reliable estimates for the activity of $\mathrm{SiO}_{2}$ and $\mathrm{TiO}_{2}\left(\mathrm{aSiO}_{2}\right.$ and $\left.\mathrm{aTiO}_{2}\right)$ during zircon crystallisation. Based on previous studies on porphyry deposits we utilise an $\mathrm{aSiO}_{2}$ of 1 and an $\mathrm{aTiO}_{2}$ of 0.7 (ChelleMichou et al., 2014; Buret et al., 2016; Tapster et al., 2016; Lee et al., 2017; Large et al., 2018), reflecting quartz and ti- tanite saturation (Claiborne et al., 2006; Ferry and Watson, 2007). Titanite saturation during zircon crystallisation is ambiguous at Batu Hijau (see discussion), but changes in the assumed $\mathrm{aTiO}_{2}$ result in systematic changes in all zircon crystallisation temperatures and will therefore not affect the interpretation of relative temperature changes: a change in the $\mathrm{aTiO}_{2}$ of \pm 0.2 would result in a variation of about $\pm 30^{\circ} \mathrm{C}$.

Imaging by cathodoluminescence (CL), followed by lowprecision but spatially resolved $\mathrm{U}-\mathrm{Pb}$ dating and geochemical microanalysis by LA-ICP-MS, was used to evaluate potential inherited zircon populations and to select inclusionfree zircons for subsequent dissolution and analysis by highprecision U-Pb geochronology by CA-ID-TIMS. Selected crystals were removed from the epoxy mount and chemically abraded (CA) for $12-15 \mathrm{~h}$ at $180^{\circ} \mathrm{C}$ using techniques modified from Mattinson (2005). Zircons were spiked with 6-8 $\mu \mathrm{g}$ of the EARTHTIME ${ }^{202} \mathrm{~Pb}-{ }^{205} \mathrm{~Pb}-{ }^{233} \mathrm{U}-{ }^{235} \mathrm{U}$ tracer solution (ET2535; Condon et al., 2015; McLean et al., 2015) and dissolved in high-pressure Parr bombs at $210^{\circ} \mathrm{C}$ for $>60 \mathrm{~h}$. Dissolved samples were dried down and redissolved in $6 \mathrm{~N} \mathrm{HCl}$ at $180^{\circ} \mathrm{C}$ for $12 \mathrm{~h}$. Sample dissolution, ion exchange chromatography modified from Krogh (1973) and loading onto zone-refined Re filaments were conducted at ETH Zürich and are described in detail by Large et al. (2018). High-precision 

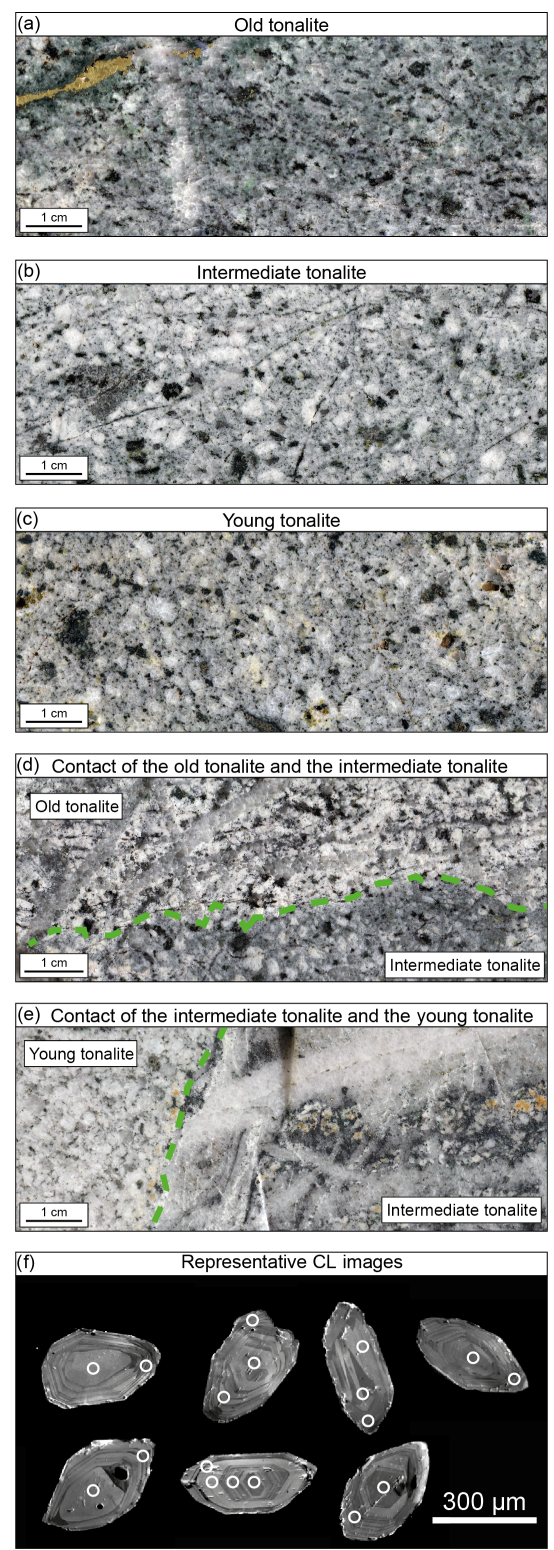

Figure 3. Rock specimens of the different tonalite porphyries and zircon CL images at Batu Hijau. Mineral assemblage in all tonalites is dominated by plagioclase, quartz and biotite. (a) Phenocrysts in the slightly propylitically altered, pre- to syn- $\mathrm{Cu}-\mathrm{Au}-$ mineralisation, equigranular old tonalite are $<3 \mathrm{~mm}$. (b) Phenocrysts of the syn-Cu-Au-mineralisation, porphyritic intermediate tonalite are $<5 \mathrm{~mm}$. (c) The post-mineralisation porphyritic young tonalite contains the largest phenocrysts $(<8 \mathrm{~mm})$ and is characterised by a higher abundance of "quartz eyes". (d) Abundant veins in the equigranular old tonalite are truncated by the later porphyritic intermediate tonalite. (e) Strongly veined intermediate tonalite is truncated by the barren and little-altered young tonalite. Dashed-green lines indicate intrusive contacts. (f) Representative zircons that display dominant oscillatory zoning and areas with little zoning. Circles indicate domains selected for LA-ICP-MS analyses ( $30 \mu \mathrm{m}$ in diameter).
$\mathrm{U}-\mathrm{Pb}$ isotopic data were obtained by employing thermal ionisation mass spectrometry at ETH Zürich (Thermo Scientific TRITON Plus). $\mathrm{Pb}$ was measured sequentially on a dynamic MasCom secondary electron multiplier, and U was measured in static mode as U oxide using Faraday cups fitted with $10^{13}$ $\Omega$ resistor amplifiers (von Quadt et al., 2016; Wotzlaw et al., 2017). Data reduction and age calculation were performed using the algorithms and software described in McLean et al. (2011) and Bowring et al. (2011). All ${ }^{206} \mathrm{~Pb} /{ }^{238} \mathrm{U}$ dates were corrected for initial ${ }^{230} \mathrm{Th}-{ }^{238} \mathrm{U}$ disequilibrium in the ${ }^{238} \mathrm{U}^{206} \mathrm{~Pb}$ decay chain (e.g. Schärer, 1984) using a constant $\mathrm{Th} / \mathrm{U}$ partition coefficient ratio of 0.25 (Rubatto and Hermann, 2007), assuming that variations in $\mathrm{Th} / \mathrm{U}$ of the zircons result from different $\mathrm{Th} / \mathrm{U}$ of the crystallising melt and not from variations in relative zircon-melt partitioning of $\mathrm{Th}$ and $\mathrm{U}$. High-precision $\mathrm{U}-\mathrm{Pb}$ dates were obtained from 45 zircons, all of which were previously analysed by LA-ICPMS.

\section{Results}

\subsection{Optical zircon appearance and SEM-CL petrography}

Zircon crystals from all three tonalite samples are colourless, euhedral to subhedral and variable in size, with $c$ axis lengths of $100-500 \mu \mathrm{m}$ and aspect ratios between $1: 2$ and $1: 4$ (Fig. 3f). Thin-section observations reveal zircons that are enclosed by phenocrysts and also occur within the finegrained groundmass, suggesting protracted zircon crystallisation within the magma until emplacement of the tonalite porphyries. Investigation of mineral separates and mounts with a binocular microscope reveals that many zircons contain small $(\ll 20 \mu \mathrm{m})$ mineral or melt inclusions. SEM-CL imaging reveals few non-zoned and sector-zoned zircon domains, but most zircons exhibit oscillatory zoning (Fig. 3f).

Only few broken zircon fragments could be identified from heavy mineral separates of the equigranular quartz diorite, but these indicate originally euhedral to subhedral shapes. Five of these broken grains, typically $<200 \mu \mathrm{m}$ long, could be identified and were mounted. Four zircons were nonzoned, and one was oscillatory-zoned.

\subsection{Spatially resolved zircon trace element composition}

At Batu Hijau, zircon geochemical analyses from the three tonalites display largely overlapping arrays and ranges for all analysed trace element concentrations and ratios (Fig. 4). Most zircons from the tonalites display systematically higher heavy rare earth elements (HREEs; e.g. Yb) over middle rare earth elements (MREEs; e.g. Dy) and light rare earth elements (LREEs; e.g. Nd) contents in their rims relative to their cores (Fig. 4a). This strongly correlates with core-rim systematics of other differentiation proxies, like increasing Hf or decreasing Th/U (Fig. 4: Hoskin and Ireland, 2000; Claiborne et al., 2006, 2010b; Schaltegger et al., 2009; Sam- 
perton et al., 2015). However, some core-rim trends, especially from the young tonalite, display increasing $\mathrm{Th} / \mathrm{U}$ and decreasing $\mathrm{Yb} /$ Dy ratios (Fig. 4b).

In most zircons, Ti concentrations decrease from core to rim (Fig. 4d, f). This decrease correlates well with increasing $\mathrm{Hf}$ and decreasing $\mathrm{Th} / \mathrm{U}$. Maximum and minimum Ti contents for all intrusions are $\sim 10$ and $\sim 2 \mathrm{ppm}$, resulting in model crystallisation temperatures of 770 to $650^{\circ} \mathrm{C}$ (see methods for details). The majority of zircons from the Batu Hijau deposit contain lower U concentrations $(<75 \mathrm{ppm})$ compared to zircons from most other porphyry deposits (several $100 \mathrm{ppm}$ ), but individual zircons can contain up to $300 \mathrm{ppm}$ (Fig. 4c). The zircons with high $\mathrm{U}$ concentrations do not correspond to the lower-Th/U zircons but also contain high Th concentrations and cover the whole spectra of $\mathrm{Th} / \mathrm{U}$ ratios observed at Batu Hijau (Fig. 4c). The Eu anomaly $\left(\mathrm{Eu} / \mathrm{Eu}^{*}\right.$, which is a means to quantify the negative inflexure of the normalised rare earth element, REE, diagram), increases (Eu / $\mathrm{Eu}^{*}$ decrease) with increasing Hf concentration (Fig. 4e). Zircon analyses from the equigranular quartz diorite plot towards the lowest $\mathrm{Hf}, \mathrm{Yb} / \mathrm{Dy}, \mathrm{Yb} / \mathrm{Nd}$ and $\mathrm{Eu} / \mathrm{Eu}^{*}$ but highest $\mathrm{Th} / \mathrm{U}$ and $\mathrm{Ti}$ end of the trends displayed by all tonalite zircons (Fig. 4).

Probability density functions (Vermeesch, 2012) are used to test for statistically significant differences between the overlapping zircon populations of the different tonalites and between core and rim analyses from the same tonalite porphyries (Fig. 4f, g, h). The Hf and Ti concentrations as well as the Eu anomaly of zircons display overlapping distributions for the intermediate and young tonalites. The old tonalite zircon population peaks at higher Ti concentrations and $\mathrm{Eu} / \mathrm{Eu}^{*}$ as well as lower Hf concentrations than the younger tonalites. Core and rim analyses from zircons of the old tonalite document decreasing $\mathrm{Ti}$ and $\mathrm{Eu} / \mathrm{Eu}^{*}$ together with increasing $\mathrm{Hf}$ concentrations from cores to rims. Hafnium contents of the rim analyses peak at higher concentrations than the core analyses within the intermediate and young tonalite, whereas $\mathrm{Eu} / \mathrm{Eu}^{*}$ displays the opposite effect. Populations illustrating titanium concentrations of the two younger tonalites, however, display no systematic changes between core and rim.

\subsection{CA-ID-TIMS geochronology}

We dated 16 zircons of each the old and intermediate tonalite and 13 zircons of the young tonalite by high-precision CA-ID-TIMS geochronology. The youngest zircon each of the old, intermediate and young tonalite yields ${ }^{230} \mathrm{Th}^{-238} \mathrm{U}$ disequilibrium-corrected ${ }^{206} \mathrm{~Pb} /{ }^{238} \mathrm{U}$ zircon dates of $3.736 \pm$ $0.023,3.697 \pm 0.018$ and $3.646 \pm 0.022 \mathrm{Ma}$ (individual grain $\pm 2 \sigma$, Fig. 5). We interpret these dates as the time of respective porphyry emplacement based on the assumption that zircons grew at depth up to the point that the magma cooled rapidly upon injection into the sub-volcanic environment (cf. Oberli et al., 2004; Schaltegger et al., 2009; von Quadt et al., 2011; Samperton et al., 2015; Large et al., 2018). Reproducibility of the individual dates is corroborated by reproducible dates for all analysed CA-ID-TIMS standards analysed during the time of analyses of the presented samples. Standards include the Aus_Z7_5 (von Quadt et al., 2016), which contains similarly low amounts of radiogenic $\mathrm{Pb}(0.5-$ $4 \mathrm{pg}$ ) and is of Pliocene age.

Despite the small differences in emplacement age, the age sequence is consistent with field observations documenting the emplacement sequence (Fig. 3). The time intervals between emplacement of the old and intermediate tonalite and between the intermediate and young tonalite can therefore be constrained to $39 \pm 29$ and $51 \pm 28 \mathrm{kyr}$, respectively. The minimum duration of zircon crystallisation, as recorded by the oldest and youngest zircon of each sample, spreads over $246 \pm 28,212 \pm 32$ and $171 \pm 26 \mathrm{kyr}$ for the old, intermediate and young tonalite (Fig. 5). The overall duration of recorded zircon crystallisation is $336 \pm 27 \mathrm{kyr}$. Using the youngest zircon population rather than the youngest individual zircon as the best approximation for porphyry emplacement (cf. Samperton et al., 2015; Buret et al., 2016; Tapster et al., 2016) would result in slightly older emplacement ages $(\sim 20 \mathrm{kyr})$ but nearly identical durations of zircon crystallisation and time intervals between porphyry emplacement events (see Supplement). Our high-precision CA-ID-TIMS dates precisely constrain protracted zircon crystallisation over several hundred thousand years and successive emplacement of the three porphyritic tonalite bodies at Batu Hijau within $90 \pm 32$ kyr.

Ratios of Th/U obtained by CA-ID-TIMS analyses on the same sample volume illustrate no systematic variation with time. Values vary inconsistently between 0.4 and 0.6 over the whole recorded time interval (Fig. 6).

\subsection{In situ U-Pb geochronology}

Trace element and $\mathrm{U}-\mathrm{Pb}$ isotopic data were obtained for each LA-ICP-MS spot (Fig. 7) prior to CA-IC-TIMS dating. Low uranium concentrations and the young ages of the analysed zircons resulted in high individual uncertainties for individual in situ U-Pb dates (mean: $10 \%$; minimum: $3 \%$; maximum: $41 \%$ ). All individual spot analyses of the three tonalites that were not discarded due to common $\mathrm{Pb}$ or strong discordance yield Pliocene dates $(2.98 \pm 1.06-$ $4.95 \pm 0.54 \mathrm{Ma}$; Fig. 7) with no apparent inherited zircons. All in situ dates of individual samples illustrate continuous arrays and do not indicate more than one population of zircons per sample (Fig. 7). Weighted means of all zircon analyses from each tonalite are $3.879 \pm 0.027,0.065,0.32$ $(n=207$; mean square weighted deviation, MSWD $=2.1)$, $3.778 \pm 0.023,0.061,0.62(n=189$, MSWD $=2.5)$ and $3.751 \pm 0.023,0.060,0.29 \mathrm{Ma}(n=158, \mathrm{MSWD}=2.6)$ from oldest to youngest (Fig. 7), where the stated uncertainties are the standard error of the weighted mean, the standard error including an external uncertainty of $1.5 \%$ as suggested 

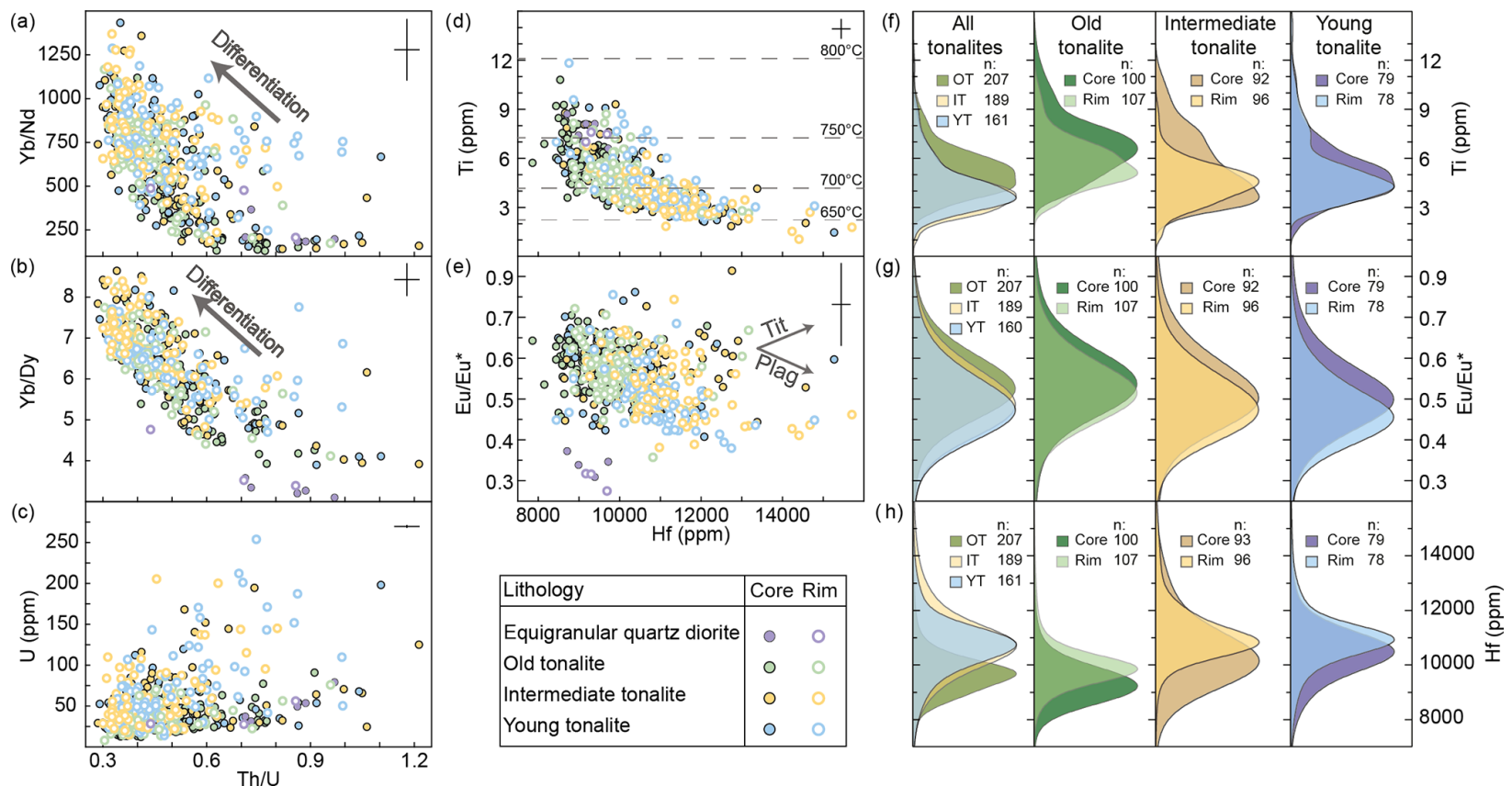

Figure 4. Covariation diagrams (a-e) and probability density plots (f-h) of in situ geochemical data obtained by LA-ICP-MS. Panels (a)-(c) are plotted against $\mathrm{Th} / \mathrm{U}$ as an indicator for fractionation, whereas panels (d) and (e) are plotted against Hf as the fractionation proxy. Arrows labelled "fractional crystallisation" indicate the approximate predicted direction zircon geochemistry would migrate given fractional crystallisation of zircon \pm apatite \pm titanite \pm amphibole. Arrows labelled "plag" and "tit" point in the predicted direction of zircon geochemistry evolution during co-crystallisation with plagioclase or titanite. Zircons from the three tonalite porphyries are considered to have crystallised from the same magma reservoir, whereas zircons from the equigranular quartz diorite (purple) are unrelated (see text for discussion). Temperature lines in panel (d) are calculated with an assumed $\mathrm{aSiO}_{2}=1$ and $\mathrm{aTiO} 2=0.7$ based on Ferry and Watson (2007: see text for discussion). The crosses in the top right corners illustrate average analytical $2 \sigma$ uncertainties. Probability density plots (after Vermeesch et al., 2013) illustrate differences between different samples and core and rim analyses within each sample. The axes of probability density plots in panels (f) and (g) are aligned with the axes of panels (d) and (e).
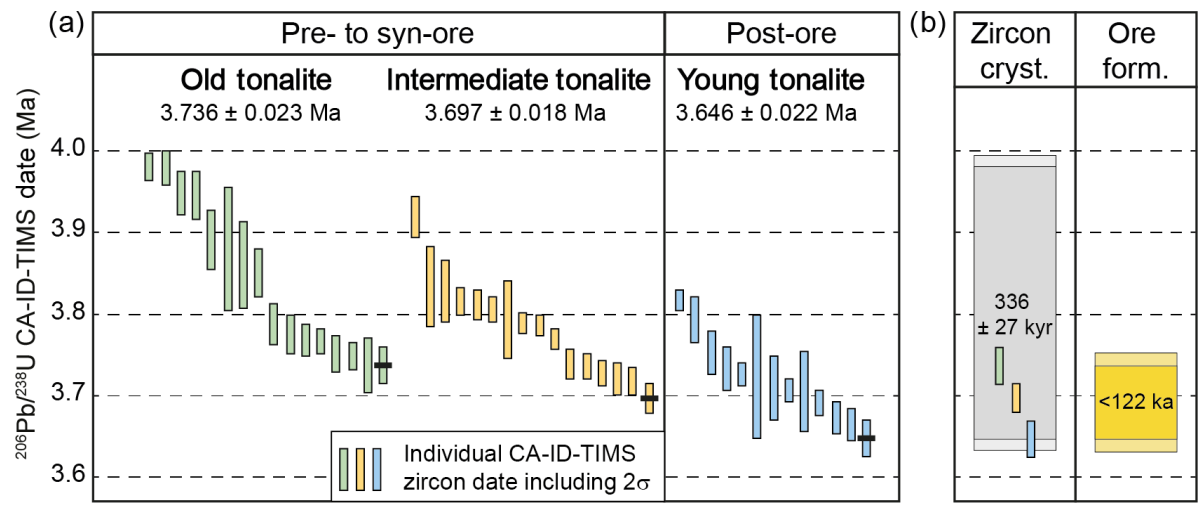

Figure 5. High-precision U-Pb CA-ID-TIMS zircon dates from the three tonalite porphyries. Vertical bars are individual analyses including analytical uncertainty $(2 \sigma)$. The youngest crystallisation age is used as the best approximation for porphyry emplacement. The extended range in zircon crystallisation ages in each sample indicates protracted crystallisation. The yellow box indicates maximum duration of ore formation as constrained by the emplacement age of the old tonalite and the young tonalite. The grey box illustrates the duration of zircon crystallisation recorded by CA-ID-TIMS geochronology. The vertical bars in the grey box are emplacement ages of the tonalites, demonstrating $>200 \mathrm{kyr}$ of zircon crystallisation before emplacement of the first porphyry intrusion and start of $\mathrm{Cu}-\mathrm{Au}$ mineralisation. 


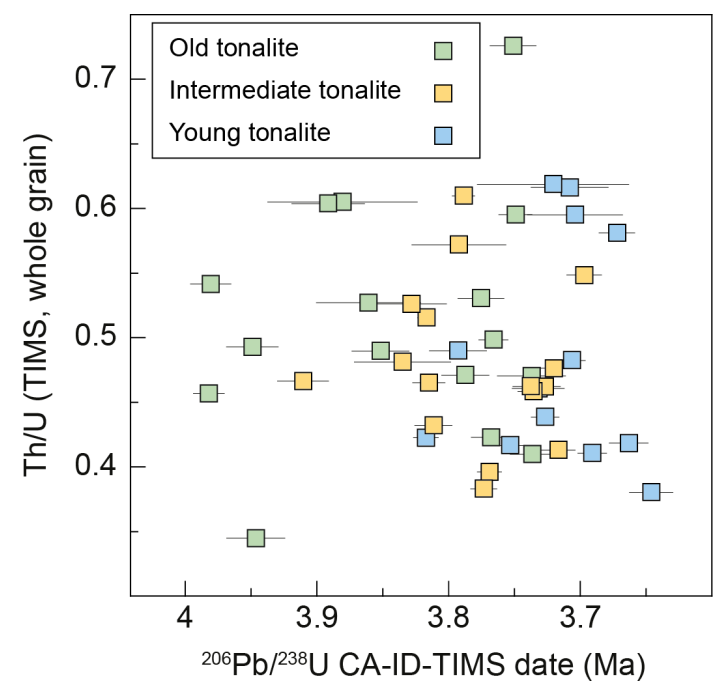

Figure 6. Th/U ratios plotted against time. Both values obtained from CA-ID-TIMS analyses of the same sample volume.

by Horstwood et al. (2016) to incorporate excess variance, and the standard deviation of zircon dates from each sample. These weighted averages do not overlap within uncertainty with the emplacement ages constrained by CA-ID-TIMS but overlap with the mean of the respective population. The few in situ analyses $(n=8)$ on zircons from the diorite result in overlapping late Miocene dates. The weighted mean of all LA-ICP-MS analyses of the equigranular diorite results in an apparent age of the equigranular diorite of $6.37 \pm 0.40$, $0.41,0.37 \mathrm{Ma}(n=8, \operatorname{MSWD}=0.46)$.

Garwin (2000) previously published SHRIMP U-Pb data on zircons from the Batu Hijau tonalites. Similar to the LAICP-MS analyses in this study, individual uncertainties of the dates were elevated $(0.12-0.30 \mathrm{Ma}, \sim 5 \%-10 \%$ uncertainty) due to low $\mathrm{U}$ concentrations and the young zircon crystallisation ages. As all dates of each sample statistically formed single populations (Supplement), weighted means were calculated of all zircons of a sample; these were interpreted as the intrusion ages of the tonalites by Garwin (2000). The reported zircon dates were not corrected for ${ }^{230} \mathrm{Th}-{ }^{238} \mathrm{U}$ disequilibrium. For comparability we will only consider zircon dates that are corrected for initial $\mathrm{Th} / \mathrm{U}$ disequilibrium (Schärer, 1984; for details consult the Supplement). Correction increases the individual zircon dates by $\sim 60-100 \mathrm{kyr}$, and recalculation of the weighted mean averages and standard errors results in dates of $3.74 \pm 0.14 \mathrm{Ma}$ (MSWD $=$ $1.2, n=8), 3.843 \pm 0.094(\mathrm{MSWD}=1.2, n=18) \mathrm{Ma}$ and $3.81 \pm 0.2 \mathrm{Ma}(\mathrm{MSWD}=2.35, n=7)$ for the old, intermediate and young tonalite, respectively.

\section{Discussion}

\subsection{Timing and duration of magmatic and hydrothermal processes leading to porphyry $\mathrm{Cu}$ formation}

The three tonalite intrusions each record protracted zircon crystallisation over $\sim 200 \mathrm{kyr}$, as resolved by high-precision ID-TIMS geochronology. The older zircon dates from the young and intermediate tonalites overlap with the younger zircons of the older intrusion(s) (Fig. 5). This overlap, together with the largely overlapping trace element systematics recorded by zircons, is used here to infer zircon crystallisation within the same mid- to upper crustal magma reservoir that sourced magmas forming the three tonalitic porphyry stocks but most likely also volatiles and metals to form the porphyry $\mathrm{Cu}-\mathrm{Au}$ deposit. High-precision geochronology records a total duration of zircon crystallisation of $336 \pm 27 \mathrm{kyr}$, which is also a minimum estimate for the lifetime of the deeper reservoir underlying Batu Hijau. The first exposed and highly mineralised tonalite intrusion (old tonalite) was injected into the upper crust $246 \pm 28 \mathrm{kyr}$ after the onset of zircon crystallisation. Emplacement of the three tonalites occurred within $90 \pm 32 \mathrm{kyr}$. Emplacement of the old tonalite was followed by the emplacement of the intermediate tonalite after $39 \pm 29 \mathrm{kyr}$, and the young tonalite was emplaced after a further $51 \pm 28 \mathrm{kyr}$.

The maximum duration of ore formation is defined by the time span between the emplacement of the pre- to synmineralisation old tonalite and the post-mineralisation young tonalite (Fig. 3d, e) and can be therefore constrained to less than 122 kyr. This maximum duration is in good agreement with previous geochronological studies indicating timescales of ore formation from $<100$ to $<29 \mathrm{kyr}$ (Figs. 8, 9; von Quadt et al., 2011; Buret et al., 2016; Tapster et al., 2016). It is also coherent with results from thermal modelling studies (Cathles, 1977; Weis et al., 2012) and modelling of diffusive fluid-rock equilibration (Cathles and Shannon, 2007; Mercer et al., 2015; Cernuschi et al., 2018) suggesting timescales of ore formation between a few thousand years and $100 \mathrm{kyr}$. Strongly elevated $\mathrm{Cu}$ and $\mathrm{Au}$ grades in the old tonalite and somewhat lower, but still economic, grades within the intermediate tonalite (Clode, 1999; Garwin, 2000; Arif and Baker, 2004) together with cross-cutting relationships (Fig. 3d, e) indicate that mineralisation occurred within at least two but possibly more pulses: (i) one strong mineralisation pulse associated with or slightly post-dating the emplacement of the old tonalite but predating the injection of the intermediate tonalite (Fig. 3d) and (ii) a second pulse is bracketed by the intrusion of the intermediate and the young tonalite (Fig. 3e). More than one episode of mineralisation is also inferred based on detailed mineralogy and vein petrography (see Geological background section; Arif and Baker, 2004; Zwyer, 2011). This further strengthens the hypothesis that individual ore-forming hydrothermal pulses are relatively short events, possibly on the millennial or sub-millennial scale (Cathles, 

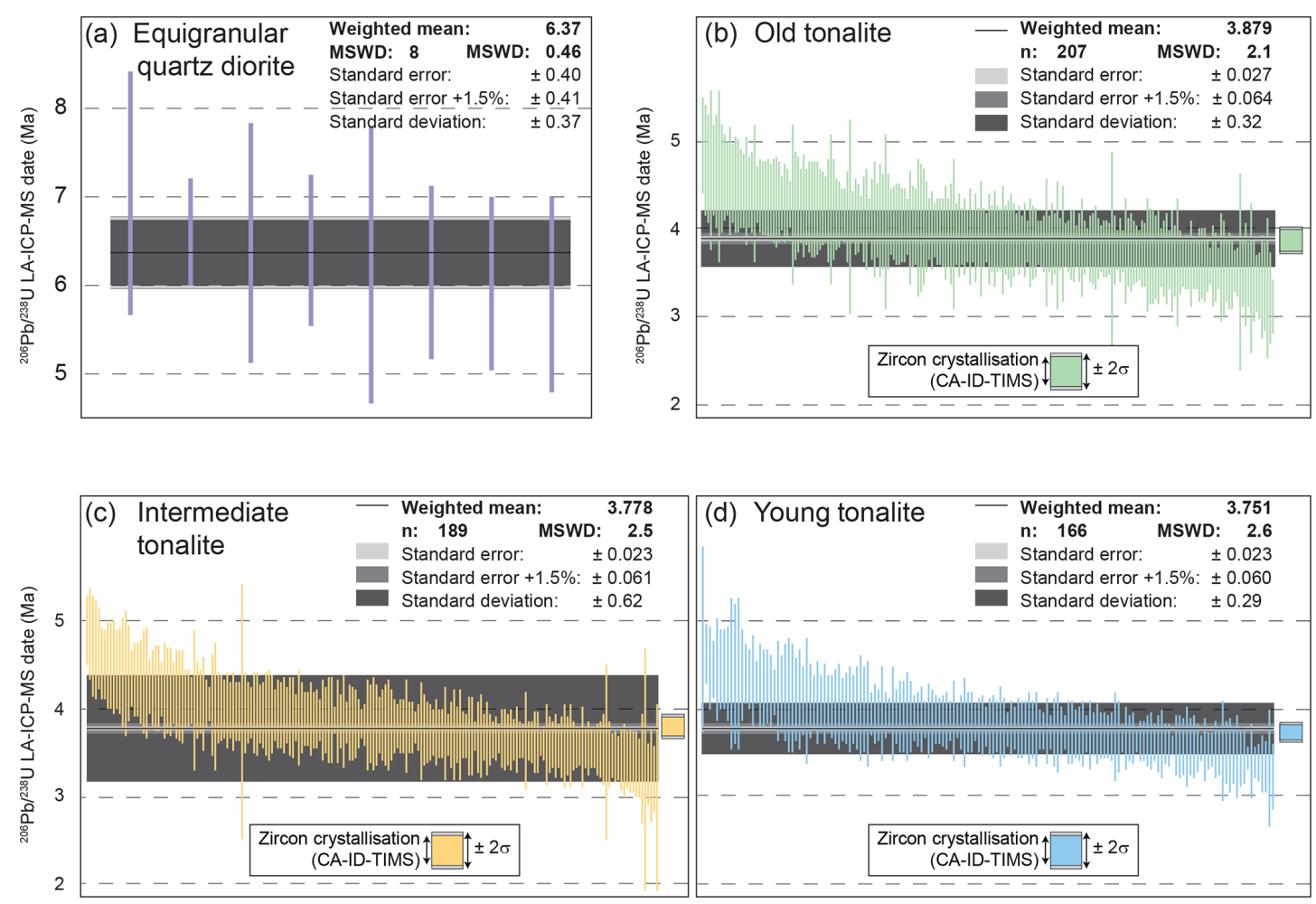

Figure 7. In situ U-Pb geochronology by LA-ICP-MS of zircons from the equigranular quartz diorite (a), the old tonalite (b), the intermediate tonalite (c) and the young tonalite (d). Vertical lines illustrate individual U-Pb dates including analytical uncertainty ( $2 \sigma)$. As no zircon populations can be separated, the weighted mean average of all analyses is calculated. Standard error (2SE, lightest grey), standard error $+1.5 \%$ (light grey) to incorporate excess variance (Horstwood et al., 2016) and standard deviation of all individual dates (dark grey) are calculated and plotted. Duration of zircon crystallisation as obtained by CA-ID-TIMS is illustrated as a box for comparison. Lower boundary of the coloured box indicates youngest CA-ID-TIMS date or the emplacement age. Note the different vertical scale in panel (a). Zircon dates from the equigranular quartz diorite are $\sim 2 \mathrm{Myr}$ older than zircons from the tonalites.

1977; Weis et al., 2012; Mercer et al., 2015), but that the formation of large economic $\mathrm{Cu}-\mathrm{Au}$ deposits occurs in several pulses over tens of thousands of years but $\leq 100 \mathrm{kyr}$ (von Quadt et al., 2011; Weis et al., 2012; Cernuschi et al., 2018).

\subsection{Reconstructing the chemical and physical evolution of a porphyry-forming magma reservoir}

$\mathrm{Th} / \mathrm{U}$ ratios and $\mathrm{Hf}$ concentrations are commonly used as proxies for the degree of crystal fractionation within a magma reservoir (e.g. Claiborne et al., 2006, 2010b; Samperton et al., 2015). The decreasing $\mathrm{Th} / \mathrm{U}$ ratios and increasing $\mathrm{Hf}$ concentrations between samples and from cores to rims (Fig. 4) are indicative of progressive melt differentiation during zircon crystallisation. The good correlation of these melt evolution proxies with decreasing Ti contents (Fig. 4) further suggests progressive cooling during differentiation. Ratios of HREE over MREE or LREE (e.g. $\mathrm{Yb} / \mathrm{Dy}, \mathrm{Yb} / \mathrm{Nd}$ ) can be utilised to make inferences about the co-crystallising mineral assemblage. Titanite for example preferentially depletes the melt in MREE, resulting in distinct trace element patterns recorded by co-crystallising zircon (e.g. Reid et al.,
2011; Wotzlaw et al., 2013; Samperton et al., 2015; Loader et al., 2017). The systematically higher HREE (e.g. Yb) over MREE (e.g. Dy) and LREE (e.g. Nd) contents in the rims of most zircons relative to their cores (Fig. 4a) thus indicate zircon crystallisation from a fractionally crystallising magma with co-crystallisation of minerals that preferentially incorporate MREE and LREE (e.g. apatite, titanite). At Batu Hijau apatites were petrographically identified, whereas magmatic titanite occurs very subordinately. The apparent lack of magmatic titanite is unusual as it is reported as a common accessory phase in many other porphyry $\mathrm{Cu}$ deposits (e.g. Bajo de la Alumbrera, El Salvador, Ok Tedi, Oyu Tolgoi). The absence of euhedral titanite within the mineral separates could be the result of dissolution during intense hydrothermal alteration (van Dongen et al., 2010).

Trace element compositions of zircons from the equigranular quartz diorite suggest crystallisation within a hotter and less evolved magma than the zircons from the tonalites (Fig. 4). In principle, this might indicate that all zircons analysed in this study have crystallised from the same reservoir, where the zircons from the equigranular quartz diorite reflect the earliest crystallised zircons from least evolved melt. 
However, the $>2$ Myr time gap is longer than the thermal lifetime of any recognised upper-crustal magmatic body (e.g. Schoene et al., 2012; Wotzlaw et al., 2013; Caricchi et al., 2014; Samperton et al., 2015; Eddy et al., 2016; Karakas et al., 2017) and longer than considered possible based on thermal modelling (Jaeger, 1957; Annen, 2009; Barboni et al., 2015). We therefore consider the zircons within the equigranular diorite to be part of a separate crustal magmatic system not directly related to the ore-forming system that sourced the three tonalitic intrusions.

Trace element populations of zircons from the three tonalites demonstrate that the crystallising magma at the time of emplacement of the old tonalite was hotter and less fractionated (Fig. 4) than at the time of emplacement of the younger intermediate and young tonalite (i.e. $39 \pm 29$ and $90 \pm 32 \mathrm{kyr}$ after emplacement of the old tonalite, respectively). The good correlation of proxies indicating progressive differentiation ( $\mathrm{Th} / \mathrm{U}$ and $\mathrm{Hf}$ ) with decreasing $\mathrm{Ti}$ concentrations (Fig. 4d) indicates that the magma reservoir cooled during concurrent crystallisation and melt evolution. In situ analyses of cores and rims are evidence of an evolving magma reservoir over the course of individual zircon crystallisation (decreasing Hf; Fig. 4h). Core-rim systematics of zircons from the old tonalite further demonstrate cooling during protracted zircon growth (Fig. 4f). Rarely recorded coherent zircon trace element systematics recording melt differentiation over time are commonly inferred to result from zircon crystallisation within a homogeneous magma that evolved continuously (e.g. Wotzlaw et al., 2013; Large et al., 2018). The lack of such systematic temporal changes in the chemistry of the zircons (Fig. 6) indicates that the magma reservoir at Batu Hijau was not evolving homogenously. This could be explained by incremental recharge or assembly of the magma reservoir. However, this would imply at least partial resetting of the intra-grain systematics recorded in zircons from the old tonalite (Buret et al., 2016; Large et al., 2018). To explain the intra-grain and intersample systematics but absence of temporal trends (Figs. 4, 6 ), we favour different degrees of crystallinity in the magma reservoir. Overall, the reservoir is generally hotter and less evolved at the time of emplacement of the old tonalite than thereafter (Fig. 4). We therefore suggest that the magma reservoir underlying Batu Hijau progressively but heterogeneously cooled and crystallised over at least $246 \pm 28 \mathrm{kyr}$, with potential incremental recharges until emplacement of the old tonalite.

A change from a differentiating, crystallising and cooling magma reservoir to a state of chemical and thermal stability is recorded between emplacement of the old and young tonalite (separated by $90 \pm 32 \mathrm{kyr}$ ) as demonstrated by the trace element systematics of the intermediate and young tonalite porphyries. The indistinguishable, highly fractionated and low-temperature zircon characteristics (Fig. 4) indicate that the magma reservoir remained in near-steadystate conditions between emplacement of the old and young tonalite as coherent intra-grain systematics are not pronounced (Hf) or are absent (Ti) in zircons from the younger tonalites (Fig. 4f, h).

Irregular zircon trace element systematics in other intrusive magmatic settings have been associated with crystallisation in non-homogenised and small melt batches sometimes, with contemporaneous incremental magma addition to the mushy magma reservoir (e.g. Schoene et al., 2012; Buret et al., 2016; Tapster et al., 2016). Geochemically similar zircon chemistries of the intermediate and young tonalite could also result from chemical stability as the magma reservoir reached the "petrological trap" at a crystallinity of 55\%-65\% (Caricchi and Blundy, 2015), where the crystal fraction does not change over a broad temperature interval. Rim analyses that plot more outside the mineral co-crystallisation trends than the respective core analyses (Fig. 4) could suggest latestage crystallisation within a nearly solidified magma that can be characterised by unsystematically variable trace element systematics (Buret et al., 2016; Lee et al., 2017). Alternatively, they could indicate thermal and possibly chemical rejuvenation of the magma (Buret et al., 2016). The latter would help explain the recorded thermal stability over tens of thousands of years. It is not possible to unambiguously identify one of the two mechanisms as dominant, and a concurrence of both is feasible. We therefore propose that in between emplacement of the old and young tonalite the underlying magma reservoir was in a thermally and chemically stable and crystal-rich state and was most likely affected by incremental magma recharge or underplating.

Our data of a porphyry-Cu-fertile magmatic system constrain a heterogeneous magma reservoir that was initially dominated by cooling and melt differentiation and evolved into a thermally and chemically stable, crystal-rich magma that possibly experienced incremental recharge. The likely transitional change of reservoir behaviour can be temporally constrained to have occurred between emplacement of the old and young tonalites and coincides with the formation of a world-class $\mathrm{Cu}-\mathrm{Au}$ reserve. This suggests that porphyry $\mathrm{Cu}-\mathrm{Au}$ deposits form after a few hundred thousand years of cooling and crystallisation, potentially within an originally melt-rich magma reservoir.

\subsection{Different timescales of processes related to porphyry $\mathrm{Cu}-\mathrm{Au}$ ore formation}

To date no clear relationship between the duration of magmatic-hydrothermal activity and the size of porphyry deposits can be identified from studies applying high-precision CA-ID-TIMS geochronology. Comparison of published datasets (Buret et al., 2016; Tapster et al., 2016; Large et al., 2018) reveals maximum durations of metal forming events of between tens of thousands of years and $10^{5} \mathrm{yr}$ (Fig. 9). Although these studies are so far constrained to deposits of $<10 \mathrm{Mt}$ of contained $\mathrm{Cu}$, they range over at least 1 order of magnitude in size (Koloula vs. Batu Hijau). A correlation 
between the duration of the mineralising or magmatic event and the total mass of deposited copper had been previously suggested based on compilations of different geochronological datasets (Chelle-Michou et al., 2017; Chiaradia and Caricchi, 2017; Chelle-Michou and Schaltegger, 2018; Chiaradia, 2020). High durations of ore formation (> $1 \mathrm{Myr}$ ) were suggested based on Re-Os geochronology on molybdenite at the giant porphyry deposits and deposit clusters in Chile (> $50 \mathrm{Gt} \mathrm{Cu}$; El Teniente, Cannell et al., 2005 and Maksaev et al., 2004; Rio Blanco, Deckart et al., 2012; and Chuquicamata, Barra et al., 2013). Mineralising timescales of copper (and gold) were calculated by subtracting the youngest from the oldest Re-Os date. However, recent Re-Os dates from El Teniente (Spencer et al., 2015) indicate that the spread in dates is more consistent with several short ( $\leq 200 \mathrm{kyr})$ hydrothermal events separated by hiatuses of $\sim 500 \mathrm{kyr}$. Thus, the large tonnage of these deposits could be the result of the superimposition of several ore-forming mid- to upper crustal magmatic systems. As the correlation of deposit size and timescales of shallow magmatic-hydrothermal systems is currently ambiguous, we would argue that other variables could be the dominant factors controlling the deposit size, such as magma reservoir size, magma or fluid chemistry, fluid release, and focusing mechanisms or the metal precipitation efficiency.

Zircon crystallisation over $\sim 200 \mathrm{kyr}$ before the onset of porphyry ore formation recorded at Batu Hijau is consistent with other high-precision geochronological studies on porphyry deposits (Figs. 8, 9: Buret et al., 2016; Tapster et al., 2016; Large et al., 2018). The lack of variation observed in these deposits suggests the necessity of a long-lived and continuously crystallising magma reservoir preceding economic ore formation. The recorded $\sim 200 \mathrm{kyr}$ of protracted zircon crystallisation could indicate a period of volatile enrichment as a result of fractional crystallisation and cooling of the magma reservoir before porphyry emplacement.

The geochronological data from the Batu Hijau district are further evidence that rapid porphyry emplacement and ore formation $(<100 \mathrm{kyr})$ are the product of a longer-term evolution (a few $100 \mathrm{kyr}$ ) of a large magma reservoir underlying the porphyry deposit that is the main driver of ore formation (von Quadt et al., 2011; Chelle-Michou et al., 2014; Buret et al., 2016, 2017; Tapster et al., 2016; Large et al., 2018). Magma reservoirs capable of forming porphyry deposits are in turn part of a longer-term (several Myr) evolution of lithosphere-scale magma systems (Sasso, 1998; Rohrlach et al., 2005; Longo et al., 2010; Rezeau et al., 2016), which is consistent with the $\gg 2 \mathrm{Myr}$ record of intrusive rocks preceding porphyry emplacement and ore formation recorded in the Batu Hijau district (Garwin, 2000; Wawryk and Foden, 2017).

\subsection{Resolving lower crustal magmatic processes from zircon petrochronology}

The lack of inheritance within the zircon record at Batu Hijau suggests that the crustal magmas experienced very minor crustal assimilation. Typically, magmas that are associated with porphyry ore formation contain diverse suites of inherited zircons (e.g. Tapster et al., 2016; Lee et al., 2017; Large et al., 2018), which have been interpreted to represent extended interaction with arc lithologies (Miller et al., 2007). This apparent lack of crustal contamination is consistent with the juvenile isotopic signatures ( $\mathrm{Pb}-\mathrm{Pb}, \mathrm{Sm}-\mathrm{Nd}, \mathrm{Rb}-\mathrm{Sr})$ of intrusions in the Batu Hijau district (Garwin, 2000; Fiorentini and Garwin, 2010). The juvenile and "porphyry-fertile" magmas at Batu Hijau have been explained by asthenospheric mantle upwelling through a tear in the subducting slab that resulted from the collision with the Roo rise (Garwin, 2000; Fiorentini and Garwin, 2010). This would also explain why the only mined porphyry deposit in the Sunda-Banda arc (Batu Hijau) and the most promising prospects (Elang and Tumpangpitu) are located above the inferred margin of the subducting Roo rise (Fig. 1).

The formation of porphyry $\mathrm{Cu}(-\mathrm{Au})$ deposits has been commonly associated with the fractionation of amphibole \pm garnet in thickened crust (e.g. Rohrlach et al., 2005; Lee and Tang, 2020) within lower crustal magma reservoirs that are active over several million years (Rohrlach et al., 2005). Zircons have been suggested to directly track this extended lower crustal history (Rohrlach et al., 2005). At Batu Hijau no zircon was identified that crystallised in a resolvable way before the main crystallisation period, which we consider to have occurred in the mid- to upper crust (Fig. 5, and discussion above). Non-zoned cores surrounded by oscillatory zoned rims (Fig. 3f) could be interpreted to reflect a twostage crystallisation process; however, the depth of these two processes cannot be resolved, and they would have occurred within the few hundred thousand years of recorded zircon crystallisation (Fig. 5). As most crystals within a mount are not polished exactly to their centre, the non-zoned cores could equally likely represent a polishing effect where the surface of one zone appears as an non-zoned core. Therefore, it is highly speculative to directly relate zircon textures to a locus or style of zircon crystallisation.

In the case of Batu Hijau, petrochronological data were used to reconstruct the mid- to upper crustal magma evolution, but the data can only provide indirect information about the lower crustal processes involved in the formation of the deposit. For example, the overall elevated $\mathrm{Eu} / \mathrm{Eu}^{*}$ of the investigated zircons (0.4-0.7; cf. Loader et al., 2017) could be the result of amphibole fractionation in the lower crust, which would have relatively enriched the residual melt Eu compared to the other REE. This would be analogous to elevated whole-rock Sr / Y ratios in exposed rocks being indicative of the lower crustal fractionating assemblage (Rohrlach et al., 2005; Chiaradia, 2015). The intra-crystal and intra- 

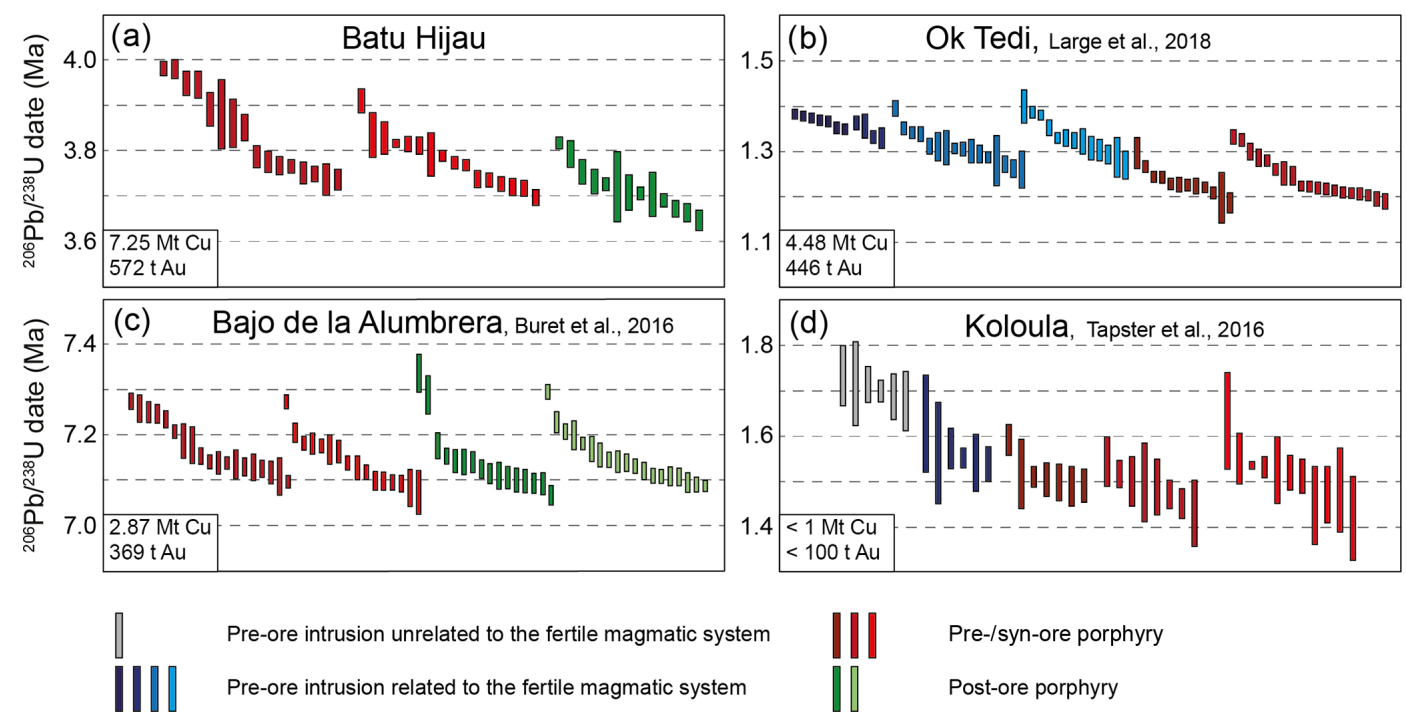

Pre-ore intrusion unrelated to the fertile magmatic system
Pre-ore intrusion related to the fertile magmatic system

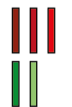

Pre-/syn-ore porphyry

Post-ore porphyry

Figure 8. Compilation of high-precision datasets on several pre-, syn- and post-ore intrusions at magmatic-hydrothermal $\mathrm{Cu}-\mathrm{Au}$ deposits. Data for Ok Tedi, Bajo de la Alumbrera and Koloula are from Large et al. (2018) Buret et al. (2016) and Tapster et al. (2016), respectively. Coloured vertical bars are individual analyses including analytical uncertainty $(2 \sigma)$. Intrusions are categorised as pre-ore, pre-/syn-ore and post-ore intrusion. Decreasing deposit size from left to right (tonnages from Cooke et al., 2005).

\section{Batu Hijau Ok Tedi Bajo de Koloula} la Alumbrera

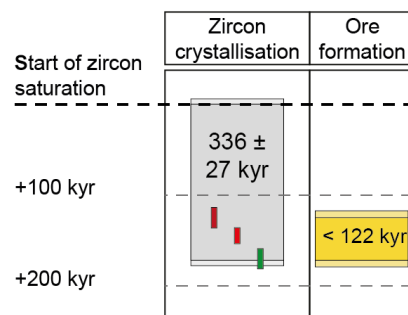

$7.25 \mathrm{Mt} \mathrm{Cu}$

Pre-ore intrusion related to the fertile magmatic system

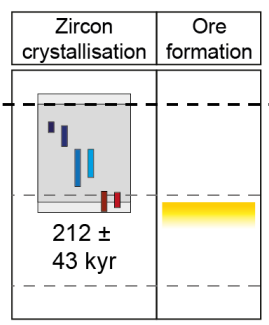

$4.48 \mathrm{Mt} \mathrm{Cu}$

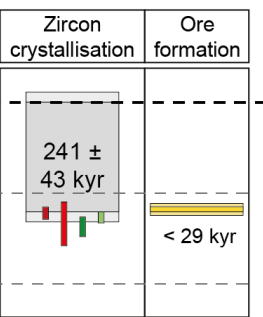

$2.87 \mathrm{Mt} \mathrm{Cu}$

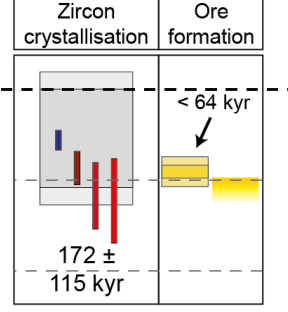

$<1 \mathrm{Mt} \mathrm{Cu}$

|| 1 Pre-/syn-ore porphyry
(USGS)

| Post-ore porphyry

Figure 9. Overview of high-precision geochronology studies on porphyry deposits. Data for Ok Tedi, Bajo de la Alumbrera and Koloula are from Large et al. (2018), Buret et al. (2016) and Tapster et al. (2016), respectively. Coloured vertical bars are emplacement ages of different intrusive rocks described from these deposits. Intrusions are categorised as pre-ore, pre- and syn-ore, and post-ore intrusion. Deposit size decreases from left to right (tonnages from Cooke et al., 2005). Diagrams are aligned so that the onset of zircon crystallisation overlaps in all deposits. Grey bars indicate the recorded duration of zircon crystallisation. Yellow bars illustrate the maximum durations of total ore formation or individual ore formation pulses. The yellow bar fading out downwards indicates the absence of a post-ore intrusion and the inability to constrain the total duration of ore formation. Note that we excluded the sample X176 from Koloula as it is not related to magmatic history leading to ore formation (Tapster et al., 2016).

sample trends of decreasing $\mathrm{Eu} / \mathrm{Eu}^{*}$ discussed above describe the evolution within the mid- to upper crustal magma reservoir that was dominated by plagioclase crystallisation and do not reflect any lower crustal process. Zircon can thus directly record the mid- to upper crustal magma evolution, but the information about lower crustal processes is limited to potentially identifying the chemistry of melt and magma that was injected from below into the mid- to upper crust, where zircon started crystallising.

\subsection{An assessment of the accuracy and precision of CA-ID-TIMS and in situ U-Pb zircon geochronology}

The U-Pb dataset from Batu Hijau allows a critical comparison of the two zircon $\mathrm{U}-\mathrm{Pb}$ geochronology techniques (LAICP-MS, CA-ID-TIMS) that have different analytical precision and can analyse samples on varying spatial scales. Previous investigation of the same lithologies by SHRIMP (Gar- 
win, 2000) allows further comparison. The spatially resolved and fast in situ U-Pb geochronology techniques - LA-ICPMS or secondary-ion mass spectrometry (SIMS)-SHRIMP allow the investigation of different crystal domains, whereas the much more time-consuming CA-ID-TIMS analysis of zircons or zircon fragments provides the highest analytical precision. The in situ techniques can discriminate between different zircon populations within single crystals (e.g. inheritance), whereas CA-ID-TIMS geochronology allows for an analytical precision for individual grains that is more than 10 times better, which is required to resolve rapid geochronological events. To increase precision of the in situ techniques, large numbers of individual dates that are considered to represent the same geological event are commonly used to calculate a weighted mean date and standard error of the mean (Wendt and Carl, 1991). On the other hand, the CA-IDTIMS community has started to measure only small zircon fragments to increase spatial resolution (e.g. Samperton et al., 2015; Smith et al., 2019). Here, the comparison of the different $\mathrm{U}-\mathrm{Pb}$ zircon techniques applied to the same rock suite allows an assessment of the accuracy of the techniques and of the effect of statistical treatment on the accuracy and precision of the different techniques.

At Batu Hijau, the youngest individual CA-ID-TIMS U$\mathrm{Pb}$ date of each sample is used as our best estimate for the emplacement age of the respective porphyry based on the low number of analyses and high ratio of crystallisation duration to individual uncertainty (Keller et al., 2018). The resulting porphyry emplacement ages are $3.736 \pm 0.023,3.697 \pm 0.018$ and $3.646 \pm 0.022 \mathrm{Myr}$ for the old, intermediate and young tonalite, respectively (Fig. 5). Other statistical means to determine the emplacement ages would be the calculation of a weighted mean for the youngest zircon population (e.g. Buret et al., 2016) or a stochastical sampling approach (Keller et al., 2018). We calculated each alternative and found that the emplacement ages overlap within uncertainty so that the timescales and conclusions derived from this study remain identical (see Appendix). The extended range of concordant zircon dates obtained by CA-ID-TIMS does not allow us to distinguish between different stages of zircon crystallisation within each sample (e.g. inherited vs. autocrystic), but the common geochemical trends support crystallisation within one common magma reservoir (see above). Thus, the range in zircon dates preceding emplacement is interpreted to represent zircon crystallisation within the underlying source magma reservoir over parts or, depending on the onset of zircon saturation, the entirety of its lifetime. The total recorded duration of zircon crystallisation is $336 \pm 27 \mathrm{kyr}$.

Even more so than the CA-ID-TIMS dates, in situ analyses by LA-ICP-MS illustrate an extended range of zircon dates that cannot be separated into different stages of zircon crystallisation. However, the span in zircon dates is about a magnitude higher for the in situ analyses $(1.41 \pm 0.5-$ $2.1 \pm 1.1 \mathrm{Myr})$ than that obtained by CA-ID-TIMS $(0.171 \pm$ $0.026-0.246 \pm 0.028 \mathrm{Myr})$. It could be argued that such LA-
ICP-MS data in isolation might indicate an extended period of zircon crystallisation not covered by CA-ID-TIMS data, potentially due to sampling bias or by one sample-set being inaccurate, but we suggest (see Sect. 5.6 below) that the span within the in situ data is the result of analytical scatter and potentially minor amounts of $\mathrm{Pb}$ loss or common $\mathrm{Pb}$.

Sampling bias in the selection of the zircons for CA-IDTIMS geochronology can be excluded as the analyses were conducted on chemically abraded zircons (Mattinson, 2005) that cover the oldest and youngest dates obtained by LA-ICPMS (Fig. 10). High accuracy of both CA-ID-TIMS and LAICP-MS datasets is suggested by routine measurements of secondary standards during the LA-ICP-MS analytical run (see Supplement) and regular measurements of zircon standards by CA-ID-TIMS over the period of data acquisition including the Pleistocene Aus_Z7_5 (von Quadt et al., 2016; Wotzlaw et al., 2017). The distributions of the zircon dates of each sample, as illustrated by probability density plots (Fig. 11), illustrate that the peak of the LA-ICP-MS and SHRIMP dates falls within the mean of zircon crystallisation as defined by the CA-ID-TIMS dataset. This suggests that all datasets are accurate but that the in situ data display more scatter and lower precision. LA-ICP-MS analyses record younger zircon dates for core analyses than rim analyses in 17 of 47 cases; however the LA-ICP-MS dates for core and rim always overlap within uncertainty. Direct comparison of $\mathrm{U}-\mathrm{Pb}$ dates from the same zircon crystals by the two techniques (Fig. 10) reveals that the less-precise LAICP-MS data are not correlated with the more precise TIMS ages, and the suggested dates from the two techniques do not overlap within uncertainty in some cases (6 in 47 cases for rim analyses; Fig. 10b). This could indicate that uncertainties calculated for the LA-ICP-MS data have been underestimated in relation to the achieved precision of the technique. However, due to the high number of analyses it is more likely that it is purely an effect of analytical scatter, where $5 \%$ of the data do not fall within the $95 \%$ confidence interval. This is corroborated by $\sim 7 \%$ (39/554) of LA-ICP-MS dates not overlapping with the minimum overall duration of zircon crystallisation identified by CA-ID-TIMS dates from all porphyries $(336 \pm 27 \mathrm{kyr})$. Additionally, minor amounts of $\mathrm{Pb}$ loss or common $\mathrm{Pb}$ not identified during data-screening could account for some older and younger outliers, but the overlapping peaks of the in situ populations and the mean of CA-ID-TIMS dates support no systematic bias of the bulk population to younger or older dates. It is therefore concluded that all three techniques are accurate and represent the $\sim 300-350 \mathrm{kyr}$ of zircon crystallisation. The high number of analyses obtained by LA-ICP-MS together with the lower-precision results in extreme outliers that extend the apparent duration of zircon crystallisation but can be regarded purely as a statistical sampling result that does not indicate a more extended duration of zircon crystallisation. Therefore, we consider alternative methods of estimating age uncertainties in the following section. 


\subsection{Determining geological ages, uncertainties and rates from in situ $\mathrm{U}-\mathrm{Pb}$ data}

Understanding the timing of magma emplacement, crystallisation or eruption is essential for determining dates and rates of magmatic processes and those directly related to or bracketed by them. Where high-precision CA-ID-TIMS data are not available, porphyry emplacement ages are commonly inferred by calculating a weighted mean and standard error from the youngest overlapping population of in situ $\mathrm{U}-\mathrm{Pb}$ dates (e.g. Correa et al., 2016; Rezeau et al., 2016; Lee et al., 2017). In the case of Batu Hijau such a calculation would include all LA-ICP-MS zircon dates for each sample as there is no apparent reason to exclude parts of the dataset due to inheritance, common $\mathrm{Pb}$ or $\mathrm{Pb}$ loss (Fig. 7). The resulting weighted mean dates for the old, intermediate and young tonalite are $3.879 \pm 0.027 / 0.064(\mathrm{MSWD}=2.1$, $n=207), 3.783 \pm 0.023 / 0.061(\mathrm{MSWD}=2.5, n=189)$ and $3.751 \pm 0.023 / 0.060$ (MSWD $=2.6, n=158$ ), where the first stated uncertainty is the standard error including internal uncertainties and those associated with tracer calibration (Schoene, 2014), and the second includes the added $1.5 \%$ external uncertainty as suggested by Horstwood et al. (2016) to account for excess variance. The MSWD for each dataset $(2.1-2.6)$ is elevated in respect to the sample size $(n=150-200)$ based on the formulation by Wendt and Carl (1991). This suggests either an underestimation of the individual uncertainties or that the data do not represent a normal distribution, e.g. by prolonged zircon crystallisation. However, there is no obvious treatment of the data to obtain more appropriate MSWDs. Under these conditions weighted means and standard errors should not be considered geologically meaningful according to Wendt and Carl (1991), but we nevertheless calculate these numbers to illustrate a few points below. Analogously, the weighted mean and standard error of all zircons analysed by SHRIMP from each sample results in weighted means of $3.74 \pm 0.14 \mathrm{Myr}$ (MSWD $=1.2, n=8), 3.843 \pm 0.094 \mathrm{Myr}(\mathrm{MSWD}=1.2, n=18)$ and 3.81 $\pm 0.2 \mathrm{Myr}(\mathrm{MSWD}=2.35, n=7$ ) for the old, intermediate and young tonalite, respectively (Fig. 11). The weighted means of the different tonalites obtained by LAICP-MS would be in accordance with cross-cutting relationships, whereas the SHRIMP dates overlap within uncertainty. The calculated standard errors for the LA-ICP-MS dates are significantly smaller than for the SHRIMP data. The decrease in the standard errors is directly correlated with the increasing sample size (Wendt and Carl, 1991; McLean et al., 2011b), implying that a comparably high number of SHRIMP analyses would result in similarly low standard errors. Irrespective of the different standard errors, the calculated weighted means by SHRIMP and LA-ICP-MS overlap within uncertainty, thus seemingly suggesting that both are accurate or similarly inaccurate (see below).

At Batu Hijau, emplacement ages determined by CAID-TIMS geochronology are systematically younger than the weighted mean dates calculated from in situ data (100$150 \mathrm{kyr}$, except CA-ID-TIMS and SHRIMP for the old tonalite), and the emplacement ages determined by CA-IDTIMS do not overlap with the LA-ICP-MS mean ages within their attributed uncertainties (Fig. 11). Indeed, disparities between different $\mathrm{U}-\mathrm{Pb}$ datasets on the same porphyry samples have been noted in several studies comparing high-precision CA-ID-TIMS data with in situ data (von Quadt et al., 2011; Chiaradia et al., 2013, 2014; Chelle-Michou et al., 2014; Correa et al., 2016). As there is no evidence for any systematic errors jeopardising the accuracy of any of the three methods in this study, all methods are considered accurate, and the reason for apparent discrepancy must lie in the geological interpretation of the statistical uncertainties.

The protracted zircon crystallisation identified at Batu Hijau has broader implications for the determination of magma emplacement, crystallisation or eruption ages. Extended magma reservoir lifetimes are not unique to Batu Hijau but a commonly described feature (e.g. Miller et al., 2007; Claiborne et al., 2010a; Reid et al., 2011; Buret et al., 2016). A weighted mean is a measure to quantify the mean of a population while emphasising the importance of values with low uncertainties over those with high uncertainties (Reiners et al., 2017) and is only valid in cases where the data are normally distributed around one expected value (Wendt and Carl, 1991). This is rarely the case when investigating geological processes, and indeed the presented in situ datasets record protracted zircon crystallisation (>300 kyr) in the magma reservoir that results in zircon population distributions that cannot be easily defined statistically (e.g. by a normal distribution; Figs. 5, 7; cf. Keller et al., 2018). The calculated weighted mean thus does not represent the porphyry emplacement age but the average zircon crystallisation. This is corroborated by the weighted means of the LA-ICP-MS and SHRIMP dates approximately describing the mean of the zircon populations defined by CA-ID-TIMS (Fig. 11). Therefore, the calculated weighted mean dates of datasets with a large number of dates but low precision do not necessarily describe any specific geological event, especially as the uncertainties indicated by the standard error for the LA-ICP-MS data are too small to even cover the entire recorded duration of zircon crystallisation.

Traditionally, problems related to the oversimplification associated with calculating weighted means and their standard errors in geochronology were hidden by the larger uncertainties resulting from larger analytical uncertainties and smaller sample sizes. Due to rapid data acquisition nowadays by in situ techniques, calculated standard errors can result in uncertainty envelopes of $<0.1 \%$ for a sample. In the case of the LA-ICP-MS dates from the Pliocene Batu Hijau porphyry intrusions, the standard error of the weighted mean $(\sim 1 \%$, $\sim 40 \mathrm{kyr}$ ) is on the same order of magnitude as an individual CA-ID-TIMS date and therefore smaller than the geological spread of zircon crystallisation ages. The combination of using a weighted mean to describe a non-Gaussian sample 

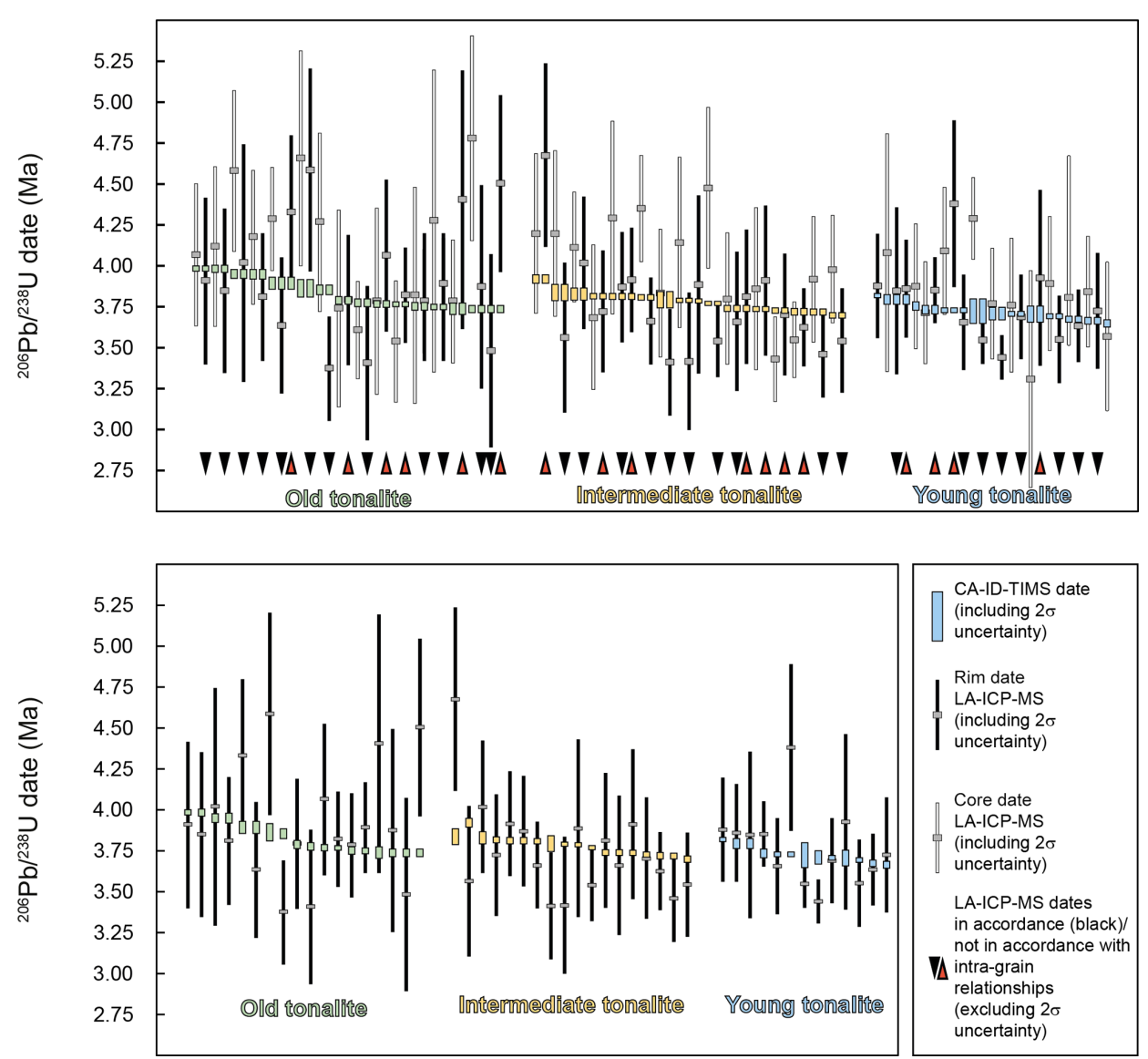

Figure 10. Comparison of in situ LA-ICP-MS dates and CA-ID-TIMS dates on the same zircons. In the upper panel each CA-ID-TIMS date is aligned with the rim (filled) and core (empty) LA-ICP-MS date of the same zircon. Coloured bars indicate individual CA-ID-TIMS analysis, including analytical uncertainty $(2 \sigma)$. Downward-pointing black arrows indicate that core analyses are older than rim analyses of the respective zircon, whereas upward-pointing red arrows indicate the opposite. Note that CA-ID-TIMS dates can be plotted several times, with core and rim analyses of the same zircon. The lower panel compares the CA-ID-TIMS date with the respective rim analysis.
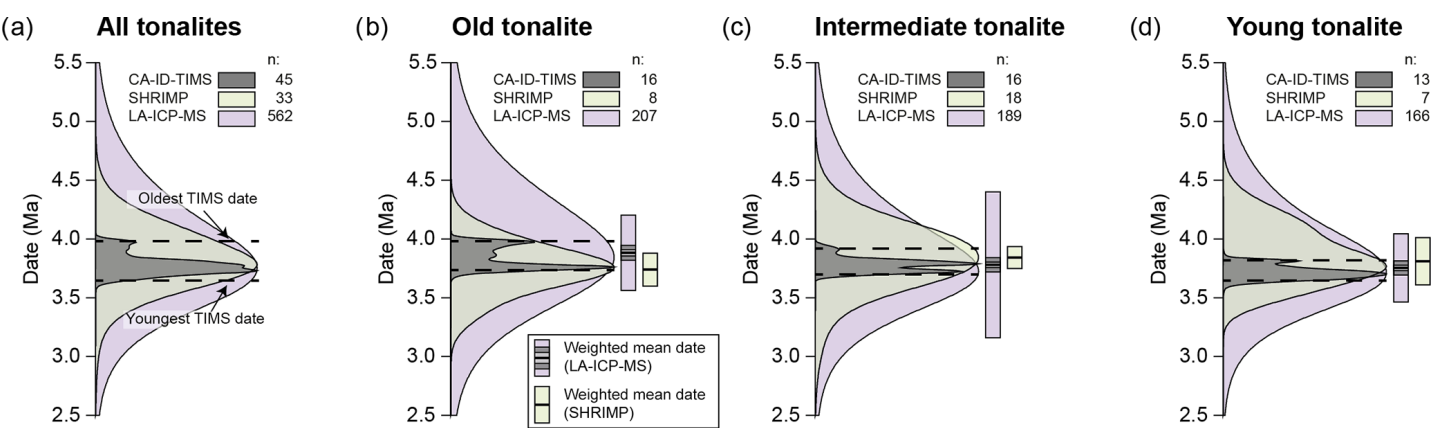

Figure 11. Probability density plots for the geochronology data for each analytical technique. All dates of each technique are combined in panel (a). Plots in panels (b), (c), and (d) are constructed from the data of the old, intermediate and young tonalite. Dashed lines indicate the youngest and oldest zircon crystallisation age as determined by CA-ID-TIMS for the respective investigated dataset. Weighted means, standard error, standard error $+1.5 \%$ (Horstwood et al., 2016) and standard deviation are shown by bars with three colours to the right of each diagram. These are identical to those in Fig. 5. 
distribution with the very small uncertainties attributed to a weighted mean results in highly precise dates that may have no relation to a specific geological event.

The MSWD (a reduced chi-square statistic) of a dataset provides a first measure to indicate whether dates are normally distributed around an expected value and thus whether the calculated weighted mean and standard error are of significance $\left(\sqrt{ }\left(\frac{2}{n-1}\right)\right.$ rule by Wendt and Carl, 1991). As discussed before, the MSWDs for the LA-ICP-MS data are elevated, implying that weighted means and standard errors should not be calculated to characterise a geological event. However, the MSWDs for the SHRIMP zircon analyses of the intermediate and old tonalite are within the $95 \%$ confidence interval of the MSWD, mainly due to the larger individual uncertainties. Still, they are similarly affected by protracted zircon crystallisation, which biases the weighted mean to higher values (Fig. 11). Furthermore, overestimated individual uncertainties can result in acceptable MSWDs but similarly inaccurate dates and low standard errors. For example, increasing individual uncertainties for the ${ }^{206} \mathrm{~Pb}-{ }^{238} \mathrm{U}$ dates obtained for the old tonalite by LA-ICP-MS by a factor of 1.5 would result in an acceptable MSWD (0.95), but the weighted mean and standard error would be nearly identically precise to those calculated with the actual uncertainties but inaccurate $(3.880 \pm 0.041,2 \mathrm{SE})$. Based on the presented data it is advised not to characterise a geological event by a weighted mean with an associated standard error if the MSWD is elevated (Wendt and Carl, 1991).

Based on the presented data we recommend using an uncertainty attributed to the weighted mean that is more representative of the uncertainty of the individual analyses so that it will most likely cover the event actually dated. Here, we tested the standard deviation of zircon dates from each sample as a measure for the uncertainty of the weighted mean. This approach provides a more realistic estimation of the uncertainty associated with calculating a weighted mean of a geologically young dataset as it describes the variability in the measurements, (0.29-0.62 Ma, Figs. 7, 11), and, importantly, it would be independent of the number of analyses. The resulting values at least for the Pliocene Batu Hijau deposit result in appropriate uncertainties for the weighted mean as it would cover an appreciable part of the range of in situ dates and thus the $>300$ kyr of zircon crystallisation and the emplacement age.

The presented data highlights the importance of CA-IDTIMS zircon U-Pb geochronology to resolve complex zircon crystallisation patterns. In the case of porphyry research, high-precision ID-TIMS dates are required to resolve the durations of porphyry emplacement and hydrothermal processes, but in situ data can reliably reconstruct a timeline of magma emplacement events within porphyry districts over million-year timescales (e.g. Rezeau et al., 2016). Furthermore, combination with in situ petrochronology techniques (i.e. U-Pb isotope and geochemical data from the same analyte) allows us to screen zircons for inheritance and more importantly provides spatially resolved geochemical information that can be integrated with high-precision dates.

\section{Conclusions}

High-precision zircon geochronology by CA-ID-TIMS combined with in situ zircon geochemistry provides valuable datasets that allow the reconstruction of geological processes with the highest temporal resolution. At Batu Hijau zircons record the magmatic-to-hydrothermal evolution of the world-class Batu Hijau porphyry $\mathrm{Cu}-\mathrm{Au}$ deposit from the onset of zircon crystallisation to emplacement of the postore young tonalite. The magma reservoir that sourced the tonalites and the $\mathrm{Cu}-\mathrm{Au}$ mineralising fluids records zircon crystallisation over $336 \pm 27$ kyr. Emplacement of the first exposed tonalite at the Batu Hijau deposit (old tonalite) occurred after $246 \pm 28 \mathrm{kyr}$ of uninterrupted zircon crystallisation in this subjacent reservoir. Zircon trace element signatures support a dominantly crystallising and cooling magma reservoir over $285 \pm 24 \mathrm{kyr}$ until emplacement of the intermediate tonalite. After emplacement of the intermediate tonalite the chemistry of the reservoir remained in rather steady conditions for $51 \pm 28 \mathrm{kyr}$, during which it could have been disturbed by magmatic recharge or underplating until final emplacement of the young tonalite. Ore formation is most probably associated with the last stages of the chemically and thermally evolving magma reservoir. The maximum duration of ore formation can be constrained to $<122 \mathrm{kyr}$ by the emplacement ages of pre-to syn-ore old tonalite and the postore young tonalite. This maximum duration of ore formation covers different pulses of mineralisation that could have lasted only a few thousand years. We record a magmatic system that was active over $\sim 250 \mathrm{kyr}$ before emplacement of the first porphyry intrusion and onset of several pulses of hydrothermal activity forming the world-class ore reserve in less than $100 \mathrm{kyr}$.

Comparison between in situ LA-ICP-MS and SHRIMP as well as CA-ID-TIMS U-Pb geochronology reveals that all techniques provide accurate individual dates (within the stated confidence interval). However, statistical treatment of in situ data by calculating a weighted mean and standard error can result in highly precise but inaccurate older ages of questionable geological significance with apparent uncertainties that do not provide an accurate measure for the uncertainty of emplacement age. The tempo of magma evolution and hydrothermal processes associated with magmatichydrothermal systems, such as porphyry deposits, is too fast to be reliably resolved by currently available in situ $\mathrm{U}-\mathrm{Pb}$ geochronology and requires ID-TIMS geochronology. Combination of high-precision geochronology with in situ or TIMS-TEA (thermal ionization mass spectrometry with trace element analysis) geochemistry is currently the most powerful tool in deciphering these geologically rapid processes. 
Data availability. All data used in this paper are available from the Supplement files.

Supplement. The supplement related to this article is available online at: https://doi.org/10.5194/gchron-2-209-2020-supplement.

Author contributions. SJEL carried out field documentation and conducted the ID-TIMS measurements. SJEL together with MG conducted the LA-ICP-MS measurements. The study was designed by SJEL, CAH, AvQ and JFW. Discussion of the data involved all authors, and SJEL wrote the manuscript and drafted the figures with input from all co-authors.

Competing interests. The authors declare that they have no conflict of interest.

Acknowledgements. Extensive logistical support by the geology department of the Batu Hijau mine, especially Eddy Priowasono, and the technical staff at the mine site was hugely appreciated. Reviews by Fernando Corfu and Brenhin Keller greatly improved the quality of this paper.

Financial support. This research has been supported by the Swiss National Science Foundation Grant (grant no. 200026166151).

Review statement. This paper was edited by Daniela Rubatto and reviewed by Brenhin Keller and Fernando Corfu.

\section{References}

Adams, C. G.: Neogene larger foraminifera, evolutionary and geological events in the context of datum planes, Pacific Neogene datum planes, 47-67, 1984.

Annen, C.: From plutons to magma chambers: Thermal constraints on the accumulation of eruptible silicic magma in the upper crust, Earth Planet. Sc. Lett., 284, 409-416, https://doi.org/10.1016/j.epsl.2009.05.006, 2009.

Arif, J. and Baker, T.: Gold paragenesis and chemistry at Batu Hijau, Indoneisa: implications for gold-rich porphyry copper deposits, Miner. Deposita, 39, 523-535, 2004.

Audétat, A., Pettke, T., Heinrich, C. A., and Bodnar, R. J.: Special paper: the composition of magmatic-hydrothermal fluids in barren and mineralized intrusions, Econ. Geol., 103, 877-908, 2008.

Banik, T. J., Coble, M. A., and Miller, C. F.: Porphyry Cu formation in the middle Jurassic Yerington batholith, Nevada, USA: Constraints from laser Raman, trace element, U-Pb age, and oxygen isotope analyses of zircon, Geosphere, 13, 1113-1132, https://doi.org/10.1130/ges01351.1, 2017.

Barberi, S., Bigioggero, B., Boriani, A., Cattaneo, M., Cavallin, A., Eva, C., Cioni, R., Gelmini, R., Giorgetti, F., and Iaccarino, S.:
The Island of Sumbawa; a major structural discontinuity in the Indonesian Arc, B. Soc. Geol. Ital., 106, 547-620, 1987.

Barboni, M., Annen, C., and Schoene, B.: Evaluating the construction and evolution of upper crustal magma reservoirs with coupled $\mathrm{U} / \mathrm{Pb}$ zircon geochronology and thermal modeling: A case study from the Mt. Capanne pluton (Elba, Italy), Earth Planet. Sc. Lett., 432, 436-448, https://doi.org/10.1016/j.eps1.2015.09.043, 2015.

Barboni, M., Boehnke, P., Schmitt, A. K., Harrison, T. M., Shane, P., Bouvier, A.-S., and Baumgartner, L.: Warm storage for arc magmas, P. Natl. Acad. Sci. USA, 113, 13959-13964, https://doi.org/10.1073/pnas.1616129113, 2016.

Barra, F., Alcota, H., Rivera, S., Valencia, V., Munizaga, F., and Maksaev, V.: Timing and formation of porphyry $\mathrm{Cu}-\mathrm{Mo}$ mineralization in the Chuquicamata district, northern Chile: new constraints from the Toki cluster, Miner. Deposita, 48, 629-651, https://doi.org/10.1007/s00126-012-0452-1, 2013.

Berggren, W. A., Kent, D. V., Swisher III, C. C., and Aubry, M.P.: A revised Cenozoic geochronology and chronostratigraphy, Geochronology Time Scales and Global Stratigraphic Correlation, SEPM Special Publication No. 54, 129-212, 1995.

Bowring, J. F., McLean, N. M., and Bowring, S.: Engineering cyber infrastructure for $\mathrm{U}-\mathrm{Pb}$ geochronology: Tripoli and U-Pb_Redux, Geochem. Geophy. Geosy., 12, https://doi.org/10.1029/2010GC003478, 2011.

Bucholz, C. E., Eddy, M. P., Jagoutz, O., Bowring, S. A., Schmidt, M. W., and Sambuu, O.: Constraining the time scales of magmatic differentiation with U-Pb zircon geochronology, Geology, 45, 11-14, https://doi.org/10.1130/g38505.1, 2017.

Buret, Y., von Quadt, A., Heinrich, C., Selby, D., Wälle, M., and Peytcheva, I.: From a long-lived upper-crustal magma chamber to rapid porphyry copper emplacement: Reading the geochemistry of zircon crystals at Bajo de la Alumbrera (NW Argentina), Earth Planet. Sc. Lett., 450, 120-131, https://doi.org/10.1016/j.epsl.2016.06.017, 2016.

Buret, Y., Wotzlaw, J.-F., Roozen, S., Guillong, M., von Quadt, A., and Heinrich, C. A.: Zircon petrochronological evidence for a plutonic-volcanic connection in porphyry copper deposits, Geology, 45, 623-626, https://doi.org/10.1130/g38994.1, 2017.

Cannell, J., Cooke, D. R., Walshe, J. L., and Stein, H.: Geology, mineralization, alteration, and structural evolution of the El Teniente porphyry Cu-Mo deposit, Econ. Geol., 100, 979-1003, 2005.

Caricchi, L. and Blundy, J.: Experimental petrology of monotonous intermediate magmas, Geological Society, London, Special Publications, 422, 105-130, https://doi.org/10.1144/sp422.9, 2015.

Caricchi, L., Simpson, G., and Schaltegger, U.: Zircons reveal magma fluxes in the Earth's crust, Nature, 511, 457-461, https://doi.org/10.1038/nature13532, 2014.

Cathles, L.: An analysis of the cooling of intrusives by ground-water convection which includes boiling, Econ. Geol., 72, 804-826, 1977.

Cathles, L. and Shannon, R.: How potassium silicate alteration suggests the formation of porphyry ore deposits begins with the nearly explosive but barren expulsion of large volumes of magmatic water, Earth Planet. Sc. Lett., 262, 92-108, 2007.

Cernuschi, F., Dilles, J. H., Grocke, S. B., Valley, J. W., Kitajima, K., and Tepley, F. J.: Rapid formation of porphyry copper de- 
posits evidenced by diffusion of oxygen and titanium in quartz, Geology, 46, 611-614, https://doi.org/10.1130/g40262.1, 2018.

Chamberlain, K. J., Wilson, C. J. N., Wooden, J. L., Charlier, B. L. A., and Ireland, T. R.: New Perspectives on the Bishop Tuff from Zircon Textures, Ages and Trace Elements, J. Petrol., 55, 395-426, https://doi.org/10.1093/petrology/egt072, 2014.

Chelle-Michou, C. and Schaltegger, U.: U-Pb dating of mineral deposits: From age constraints to ore-forming processes, EarthArXiv, https://doi.org/10.31223/osf.io/b7pw9, 2018.

Chelle-Michou, C., Chiaradia, M., Ovtcharova, M., Ulianov, A., and Wotzlaw, J.-F.: Zircon petrochronology reveals the temporal link between porphyry systems and the magmatic evolution of their hidden plutonic roots (the Eocene Coroccohuayco deposit, Peru), Lithos, 198-199, 129-140, https://doi.org/10.1016/j.lithos.2014.03.017, 2014.

Chelle-Michou, C., Rottier, B., Caricchi, L., and Simpson, G.: Tempo of magma degassing and the genesis of porphyry copper deposits, Sci. Rep., 7, 40566, https://doi.org/10.1038/srep40566, 2017.

Chiaradia, M.: Crustal thickness control on Sr/Y signatures of recent arc magmas: an Earth scale perspective, Sci. Rep., 5, 8115, https://doi.org/10.1038/srep08115, 2015.

Chiaradia, M.: Gold endowments of porphyry deposits controlled by precipitation efficiency, Nat. Commun., 11, 1-10, https://doi.org/10.1038/s41467-019-14113-1, 2020.

Chiaradia, M. and Caricchi, L.: Stochastic modelling of deep magmatic controls on porphyry copper deposit endowment, Sci. Rep., 7, 44523, https://doi.org/10.1038/srep44523, 2017.

Chiaradia, M., Schaltegger, U., Spikings, R., Wotzlaw, J.-F., and Ovtcharova, M.: How accurately can we date the duration of magmatic-hydrothermal events in porphyry systems? - an invited paper, Econ. Geol., 108, 565-584, 2013.

Chiaradia, M., Schaltegger, U., and Spikings, R. A.: Time scales of mineral systems-advances in understanding over the past decade, Building exploration capability for the 21 st century, $37-$ 58, https://doi.org/10.5382/SP.18.03, 2014.

Claiborne, L. L., Miller, C., Walker, B., Wooden, J., Mazdab, F., and Bea, F.: Tracking magmatic processes through $\mathrm{Zr} / \mathrm{Hf}$ ratios in rocks and $\mathrm{Hf}$ and $\mathrm{Ti}$ zoning in zircons: an example from the Spirit Mountain batholith, Nevada, Mineral. Mag., 70, 517-543, 2006.

Claiborne, L. L., Miller, C. F., Flanagan, D. M., Clynne, M. A., and Wooden, J. L.: Zircon reveals protracted magma storage and recycling beneath Mount St. Helens, Geology, 38, 1011-1014, https://doi.org/10.1130/g31285.1, 2010a.

Claiborne, L. L., Miller, C. F., and Wooden, J. L.: Trace element composition of igneous zircon: a thermal and compositional record of the accumulation and evolution of a large silicic batholith, Spirit Mountain, Nevada, Contrib. Mineral. Petr., 160, 511-531, https://doi.org/10.1007/s00410-010-0491-5, $2010 \mathrm{~b}$.

Clode, C.: Relationships of intrusion, wall-rock alteration and mineralization in the Batu Hijau copper-gold porphyry deposit, Proceedings, PACRIM'99 Congress, Bali, Indonesia, 485-498, 1999.

Condon, D., Schoene, B., McLean, N., Bowring, S., and Parrish, R.: Metrology and traceability of $\mathrm{U}-\mathrm{Pb}$ isotope dilution geochronology (EARTHTIME Tracer Calibration Part I), Geochim. Cosmochim. Ac., 164, 464-480, 2015.
Cooke, D. R., Hollings, P., and Walshe, J. L.: Giant porphyry deposits: characteristics, distribution, and tectonic controls, Econ. Geol., 100, 801-818, 2005.

Correa, K. J., Rabbia, O. M., Hernández, L. B., Selby, D., and Astengo, M.: The timing of magmatism and ore formation in the El Abra porphyry copper deposit, northern Chile: Implications for long-lived multiple-event magmatic-hydrothermal porphyry systems, Econ. Geol., 111, 1-28, 2016.

Deckart, K., Clark, A. H., Cuadra, P., and Fanning, M.: Refinement of the time-space evolution of the giant Mio-Pliocene Río Blanco-Los Bronces porphyry $\mathrm{Cu}-\mathrm{Mo}$ cluster, Central Chile: new U-Pb (SHRIMP II) and Re-Os geochronology and 40Ar/39Ar thermochronology data, Miner. Deposita, 48, 57-79, https://doi.org/10.1007/s00126-012-0412-9, 2012.

Deino, A. and Keith, J. D.: Ages of volcanic and intrusive rocks in the Bingham mining district, Utah, Geology and ore deposits of the Oquirrh and Wasatch mountains, Utah, Society of Economic Geologists, Guidebook Series, 29, 91-95, 1997.

Dilles, J. H.: Petrology of the Yerington Batholith, Nevada; evidence for evolution of porphyry copper ore fluids, Econ. Geol., 82, 1750-1789, 1987.

Dilles, J. H. and Einaudi, M. T.: Wall-rock alteration and hydrothermal flow paths about the Ann-Mason porphyry copper deposit, Nevada; a 6-km vertical reconstruction, Econ. Geol., 87, 19632001, 1992.

Dilles, J. H., Kent, A. J., Wooden, J. L., Tosdal, R. M., Koleszar, A., Lee, R. G., and Farmer, L. P.: Zircon compositional evidence for sulfur-degassing from ore-forming arc magmas, Econ. Geol., 110, 241-251, 2015.

Eddy, M. P., Bowring, S. A., Miller, R. B., and Tepper, J. H.: Rapid assembly and crystallization of a fossil large-volume silicic magma chamber, Geology, 44, 331-334, https://doi.org/10.1130/g37631.1, 2016.

Ferry, J. M. and Watson, E. B.: New thermodynamic models and revised calibrations for the Ti-in-zircon and $\mathrm{Zr}$-inrutile thermometers, Contrib. Mineral. Petr., 154, 429-437, https://doi.org/10.1007/s00410-007-0201-0, 2007.

Fiorentini, M. L. and Garwin, S. L.: Evidence of a mantle contribution in the genesis of magmatic rocks from the Neogene Batu Hijau district in the Sunda Arc, South Western Sumbawa, Indonesia, Contrib. Mineral. Petr., 159, 819-837, https://doi.org/10.1007/s00410-009-0457-7, 2010.

Foden, J. and Varne, R.: The petrology and tectonic setting of Quaternary - Recent volcanic centres of Lombok and Sumbawa, Sunda arc, Chem. Geol., 30, 201-226, 1980.

Garwin, S., Hall, R., and Watanabe, Y.: Tectonic setting, geology, and gold and copper mineralization in Cenozoic magmatic arcs of Southeast Asia and the West Pacific, Econ. Geol., 100th anniversary volume, 891-930, 2005.

Garwin, S. L.: The Setting, Geometry and Timing of Intrusionrelated Hydrothermal System in the Vicinity of the Batu Hijau porphyry Copper-gold deposit, Sumbawa, Indonesia, PhD Thesis, University of Western Australia, 2000.

Gilmer, A. K., Sparks, R. S. J., Rust, A. C., Tapster, S., Webb, A. D., and Barfod, D. N.: Geology of the Don Manuel igneous complex, central Chile: Implications for igneous processes in porphyry copper systems, Geol. Soc. Am. Bull., 129, 920-946, https://doi.org/10.1130/b31524.1, 2017. 
Guillong, M., von Quadt, A., Sakata, S., Peytcheva, I., and Bachmann, O.: LA-ICP-MS Pb-U dating of young zircons from the Kos-Nisyros volcanic centre, SE Aegean arc, J. Anal. Atom. Spectrom., 29, 963-970, 2014.

Hall, R.: Cenozoic geological and plate tectonic evolution of SE Asia and the SW Pacific: computer-based reconstructions, model and animations, J. Asian Earth Sci., 20, 353-431, 2002.

Halter, W. E., Bain, N., Becker, K., Heinrich, C. A., Landtwing, M., VonQuadt, A., Clark, A. H., Sasso, A. M., Bissig, T., and Tosdal, R. M.: From andesitic volcanism to the formation of a porphyry $\mathrm{Cu}-\mathrm{Au}$ mineralizing magma chamber: the Farallón Negro Volcanic Complex, northwestern Argentina, J. Volcanol. Geoth. Res., 136, 1-30, https://doi.org/10.1016/j.jvolgeores.2004.03.007, 2004.

Hamilton, W. B.: Tectonics of the Indonesian region, 1078, US Govt. Print. Off., 1979.

Horstwood, M. S. A., Košler, J., Gehrels, G., Jackson, S. E., McLean, N. M., Paton, C., Pearson, N. J., Sircombe, K., Sylvester, P., Vermeesch, P., Bowring, J. F., Condon, D. J., and Schoene, B.: Community-Derived Standards for LA-ICP-MS U(Th-)Pb Geochronology - Uncertainty Propagation, Age Interpretation and Data Reporting, Geostand. Geoanal. Res., 40, 311332, https://doi.org/10.1111/j.1751-908X.2016.00379.x, 2016.

Hoskin, P. W. and Ireland, T. R.: Rare earth element chemistry of zircon and its use as a provenance indicator, Geology, 28, 627630, 2000.

Hutchison, C. S.: Geological evolution of South-east Asia, Clarendon Press Oxford, 1989.

Idrus, A., Kolb, J., and Meyer, F. M.: Chemical Composition of Rock-Forming Minerals in Copper-Gold-Bearing Tonalite Porphyries at the Batu Hijau Deposit, Sumbawa Island, Indonesia: Implications for Crystallization Conditions and FluorineChlorine Fugacity, Resour. Geol., 57, 102-113, 2007.

Jaeger, J.: The temperature in the neighborhood of a cooling intrusive sheet, Am. J. Sci., 255, 306-318, 1957.

Karakas, O., Degruyter, W., Bachmann, O., and Dufek, J.: Lifetime and size of shallow magma bodies controlled by crustal-scale magmatism, Nat. Geosci., 10, 446-450, https://doi.org/10.1038/ngeo2959, 2017.

Keller, C. B., Schoene, B., and Samperton, K. M.: A stochastic sampling approach to zircon eruption age interpretation, Geochemical Perspectives Letters, 8. 31-35, https://doi.org/10.7185/geochemlet.1826, 2018.

Krogh, T.: A low-contamination method for hydrothermal decomposition of zircon and extraction of $\mathrm{U}$ and $\mathrm{Pb}$ for isotopic age determinations, Geochim. Cosmochim. Ac., 37, 485-494, 1973.

Landtwing, M., Pettke, T., Halter, W., Heinrich, C., Redmond, P., Einaudi, M., and Kunze, K.: Copper deposition during quartz dissolution by cooling magmatic-hydrothermal fluids: The Bingham porphyry, Earth Planet. Sc. Lett., 235, 229-243, https://doi.org/10.1016/j.epsl.2005.02.046, 2005.

Large, S. J. E., Bakker, E. Y. N., Weis, P., Wälle, M., Ressel, M., and Heinrich, C. A.: Trace elements in fluid inclusions of sediment-hosted gold deposits indicate a magmatichydrothermal origin of the Carlin ore trend, Geology, 44, 10151018, https://doi.org/10.1130/g38351.1, 2016.

Large, S. J. E., von Quadt, A., Wotzlaw, J.-F., Guillong, M., and Heinrich, C. A.: Magma Evolution Leading to Porphyry $\mathrm{Au}-\mathrm{Cu}$ Mineralization at the Ok Tedi Deposit, Papua
New Guinea: Trace Element Geochemistry and High-Precision Geochronology of Igneous Zircon, Econ. Geol., 113, 39-61, https://doi.org/10.5382/econgeo.2018.4543, 2018.

Lee, C.-T. A. and Tang, M.: How to make porphyry copper deposits, Earth Planet. Sc. Lett., 529, 115868, https://doi.org/10.1016/j.epsl.2019.115868, 2020.

Lee, R. G., Dilles, J. H., Tosdal, R. M., Wooden, J. L., and Mazdab, F. K.: Magmatic Evolution of Granodiorite Intrusions at the El Salvador Porphyry Copper Deposit, Chile, Based on Trace Element Composition and U/Pb Age of Zircons, Econ. Geol., 112, 245-273, https://doi.org/10.2113/econgeo.112.2.245, 2017.

Loader, M. A., Wilkinson, J. J., and Armstrong, R. N.: The effect of titanite crystallisation on $\mathrm{Eu}$ and $\mathrm{Ce}$ anomalies in zircon and its implications for the assessment of porphyry $\mathrm{Cu}$ deposit fertility, Earth Planet. Sc. Lett., 472, 107-119, https://doi.org/10.1016/j.eps1.2017.05.010, 2017.

Longo, A. A., Dilles, J. H., Grunder, A. L., and Duncan, R.: Evolution of calc-alkaline volcanism and associated hydrothermal gold deposits at Yanacocha, Peru, Econ. Geol., 105, 1191-1241, 2010.

Maksaev, V., Munizaga, F., McWilliams, M., Fanning, M., Mathur, R., Ruiz, J., and Zentilli, M.: New chronology for El Teniente, Chilean Andes, from U-Pb, 40Ar/39Ar, Re-Os, and fission-track dating: Implications for the evolution of a supergiant porphyry Cu-Mo deposit, Soc. Eco. Geo., 11, 15-54, 2004.

Mattinson, J. M.: Zircon U-Pb chemical abrasion ("CA-TIMS") method: combined annealing and multi-step partial dissolution analysis for improved precision and accuracy of zircon ages, Chem. Geol., 220, 47-66, 2005.

McLean, N. M., Bowring, J. F., and Bowring, S. A.: An algorithm for $\mathrm{U}-\mathrm{Pb}$ isotope dilution data reduction and uncertainty propagation, Geochem., Geophy. Geosy., 12, 6, https://doi.org/10.1029/2010gc003478, 2011.

McLean, N. M., Condon, D. J., Schoene, B., and Bowring, S. A.: Evaluating uncertainties in the calibration of isotopic reference materials and multi-element isotopic tracers (EARTHTIME Tracer Calibration Part II), Geochim. Cosmochim. Ac., 164, 481-501, 2015.

Meldrum, S. J., Aquino, R. S., Gonzales, R. I., Burke, R. J., Suyadi, A., Irianto, B., and Clarke, D. S.: The Batu Hijau porphyry copper-gold deposit, Sumbawa Island, Indonesia, J. Geochem. Explor., 50, 203-220, https://doi.org/10.1016/03756742(94)90025-6, 1994.

Mercer, C. N., Reed, M. H., and Mercer, C. M.: Time scales of porphyry $\mathrm{Cu}$ deposit formation: insights from titanium diffusion in quartz, Econ. Geol., 110, 587-602, 2015.

Miller, J. S., Matzel, J. E. P., Miller, C. F., Burgess, S. D., and Miller, R. B.: Zircon growth and recycling during the assembly of large, composite arc plutons, J. Volcanol. Geoth. Res., 167, 282-299, https://doi.org/10.1016/j.jvolgeores.2007.04.019, 2007.

Mitchell, P., Proffett, J., and Dilles, J.: Geological review of the Batu Hijau porphyry copper-gold deposit, Sumbawa Island, Indonesia, Newmont Nusa Tenggara Company Final report, PT Newmont Nusa Tenggara, Batu Hijau project, Sumbawa, Indonesia, 164 pp., 1998.

Oberli, F., Meier, M., Berger, A., Rosenberg, C. L., and GierÉ, R.: $\mathrm{U}-\mathrm{Th}-\mathrm{Pb}$ and $230 \mathrm{Th} / 238 \mathrm{U}$ disequilibrium isotope systematics: Precise accessory mineral chronology and melt evolution tracing in the Alpine Bergell intrusion, Geochim. Cosmochim. Ac., 68, 2543-2560, https://doi.org/10.1016/j.gca.2003.10.017, 2004. 
Proffett, J. M.: Geology of the Bajo de la Alumbrera porphyry copper-gold deposit, Argentina, Econ. Geol., 98, 1535-1574, 2003.

Proffett, J. M.: High $\mathrm{Cu}$ grades in porphyry $\mathrm{Cu}$ deposits and their relationship to emplacement depth of magmatic sources, Geology, 37, 675-678, https://doi.org/10.1130/g30072a.1, 2009.

Redmond, P. B. and Einaudi, M. T.: The Bingham Canyon porphyry $\mathrm{Cu}-\mathrm{Mo}-\mathrm{Au}$ deposit. I. Sequence of intrusions, vein formation, and sulfide deposition, Econ. Geol., 105, 43-68, 2010.

Reid, M. R., Vazquez, J. A., and Schmitt, A. K.: Zirconscale insights into the history of a Supervolcano, Bishop Tuff, Long Valley, California, with implications for the Ti-inzircon geothermometer, Contrib. Mineral. Petr., 161, 293-311, https://doi.org/10.1007/s00410-010-0532-0, 2011.

Reiners, P. W., Carlson, R. W., Renne, P. R., Cooper, K. M., Granger, D. E., McLean, N. M., and Schoene, B.: Interpretational approaches: making sense of data, in: Geochronology and thermochronology, John Wiley \& Sons, 2017.

Rezeau, H., Moritz, R., Wotzlaw, J.-F., Tayan, R., Melkonyan, R., Ulianov, A., Selby, D., d'Abzac, F.-X., and Stern, R. A.: Temporal and genetic link between incremental pluton assembly and pulsed porphyry $\mathrm{Cu}-\mathrm{Mo}$ formation in accretionary orogens, $\mathrm{Ge}-$ ology, 44, 627-630, https://doi.org/10.1130/g38088.1, 2016.

Richards, J. P.: Giant ore deposits formed by optimal alignments and combinations of geological processes, Nat. Geosci., 6, 911916, https://doi.org/10.1038/ngeo1920, 2013.

Roedder, E.: Fluid inclusion studies on the porphyry-type ore deposits at Bingham, Utah, Butte, Montana, and Climax, Colorado, Econ. Geol., 66, 98-118, 1971.

Rohrlach, B. D., Loucks, R. R., and Porter, T.: Multi-Million-Year Cyclic Ramp-up of Volatiles in a Lower Crustal Magma Reservoir Trapped Below the Tampakan Copper-Gold Deposit by MioPliocene Crustal Compression in the Southern Philippines, in: 2005 Super Porphyry Copper \& Gold Deposits - A Global Perspective, edited by: Porter, T. M., PGC Publishing, Adelaide, v.2, 369-407, 2005.

Rubatto, D. and Hermann, J.: Experimental zircon/melt and zircon/garnet trace element partitioning and implications for the geochronology of crustal rocks, Chem. Geol., 241, 38-61, https://doi.org/10.1016/j.chemgeo.2007.01.027, 2007.

Samperton, K. M., Schoene, B., Cottle, J. M., Brenhin Keller, C., Crowley, J. L., and Schmitz, M. D.: Magma emplacement, differentiation and cooling in the middle crust: Integrated zircon geochronological-geochemical constraints from the Bergell Intrusion, Central Alps, Chem. Geol., 417, 322-340, https://doi.org/10.1016/j.chemgeo.2015.10.024, 2015.

Sasso, A.: The Farallón Negro Group, northwest Argentina: magmatic, hydrothermal and tectonic evolution and implications for $\mathrm{Cu}-\mathrm{Au}$ metallogeny in the Andean back-arc, Soc. Econ. Geol. Newsletter, 34, 8-18, 1998.

Schaltegger, U., Brack, P., Ovtcharova, M., Peytcheva, I., Schoene, B., Stracke, A., Marocchi, M., and Bargossi, G. M.: Zircon and titanite recording 1.5 million years of magma accretion, crystallization and initial cooling in a composite pluton (southern Adamello batholith, northern Italy), Earth Planet. Sc. Lett., 286, 208-218, https://doi.org/10.1016/j.epsl.2009.06.028, 2009.

Schärer, U.: The effect of initial 230 Th disequilibrium on young U Pb ages: The Makalu case, Himalaya, Earth Planet. Sc. Lett., 67, 191-204, 1984.
Schoene, B.: U-Th-Pb Geochronology, in: Treatise on Geochemistry, 4, 341-378, 2014.

Schoene, B., Schaltegger, U., Brack, P., Latkoczy, C., Stracke, A., and Günther, D.: Rates of magma differentiation and emplacement in a ballooning pluton recorded by U-Pb TIMS-TEA, Adamello batholith, Italy, Earth Planet. Sc. Lett., 355-356, 162173, https://doi.org/10.1016/j.eps1.2012.08.019, 2012.

Schirra, M., Driesner, T., and Heinrich, C. A.: Relative timing of sulfide precipitation at the Batu Hijau porphyry $\mathrm{Cu}-\mathrm{Au}$ deposit, Sumbawa, Indonesia, Life with Ore Deposits on Earth, Proceedings of the 15th SGA Biennial Meeting, Glasgow, 1009-1012, 2019.

Seedorff, E. and Einaudi, M. T.: Henderson porphyry molybdenum system, Colorado: I. Sequence and abundance of hydrothermal mineral assemblages, flow paths of evolving fluids, and evolutionary style, Econ. Geol., 99, 3-37, 2004.

Seedorff, E., Barton, M. D., Stavast, W. J., and Maher, D. J.: Root zones of porphyry systems: Extending the porphyry model to depth, Econ. Geol., 103, 939-956, 2008.

Setyandhaka, D., Arif, J., and Proffett, J. M.: Characteristics of the root of a classic $\mathrm{Cu}$-Au porphyry system: The Batu Hijau porphyry deposit, Indonesia, PACRIM Congress 2008, Australasian Institute of Mining and Metallurgy (AusIMM), Brisbane, Australia, Proceedings, 8 pp., 2008.

Sillitoe, R. H.: Porphyry copper systems, Econ. Geol., 105, 3-41, 2010.

Smith, W. D., Darling, J. R., Bullen, D. S., Lasalle, S., Pereira, I., Moreira, H., Allen, C. J., and Tapster, S.: Zircon perspectives on the age and origin of evolved S-type granites from the Cornubian Batholith, Southwest England, Lithos, 336-337, 14-26, https://doi.org/10.1016/j.lithos.2019.03.025, 2019.

Spencer, E. T., Wilkinson, J. J., Creaser, R. A., and Seguel, J.: The distribution and timing of molybdenite mineralization at the El Teniente Cu-Mo porphyry deposit, Chile, Econ. Geol., 110, 387421, 2015.

Steinberger, I., Hinks, D., Driesner, T., and Heinrich, C. A.: Source plutons driving porphyry copper ore formation: combining geomagnetic data, thermal constraints, and chemical mass balance to quantify the magma chamber beneath the Bingham Canyon deposit, Econ. Geol., 108, 605-624, 2013.

Szymanowski, D., Wotzlaw, J.-F., Ellis, B. S., Bachmann, O., Guillong, M., and von Quadt, A.: Protracted near-solidus storage and pre-eruptive rejuvenation of large magma reservoirs, Nat. Geosci., 10, 777-782, https://doi.org/10.1038/ngeo3020, 2017.

Tapster, S., Condon, D. J., Naden, J., Noble, S. R., Petterson, M. G., Roberts, N. M. W., Saunders, A. D., and Smith, D. J.: Rapid thermal rejuvenation of high-crystallinity magma linked to porphyry copper deposit formation; evidence from the Koloula Porphyry Prospect, Solomon Islands, Earth Planet. Sc. Lett., 442, 206-217, https://doi.org/10.1016/j.epsl.2016.02.046, 2016.

van Dongen, M., Weinberg, R. F., and Tomkins, A. G.: REE-Y, Ti, and $\mathrm{P}$ remobilization in magmatic rocks by hydrothermal alteration during $\mathrm{Cu}-\mathrm{Au}$ deposit formation, Econ. Geol., 105, 763776, 2010.

Vazquez, J. A. and Reid, M. R.: Probing the accumulation history of the voluminous Toba magma, Science, 305, 991-994, https://doi.org/10.1126/science.1096994, 2004. 
Vermeesch, P.: On the visualisation of detrital age distributions, Chem. Geol., 312-313, 190-194, https://doi.org/10.1016/j.chemgeo.2012.04.021, 2012.

von Quadt, A., Erni, M., Martinek, K., Moll, M., Peytcheva, I., and Heinrich, C. A.: Zircon crystallization and the lifetimes of ore-forming magmatic-hydrothermal systems, Geology, 39, 731734, https://doi.org/10.1130/g31966.1, 2011.

von Quadt, A., Wotzlaw, J.-F., Buret, Y., Large, S. J., Peytcheva, I., and Trinquier, A.: High-precision zircon $\mathrm{U} / \mathrm{Pb}$ geochronology by ID-TIMS using new $10^{13} \mathrm{ohm}$ resistors, J. Anal. Atom. Spectrom., 31, 658-665, 2016.

Watson, E. and Harrison, T.: Zircon thermometer reveals minimum melting conditions on earliest Earth, Science, 308, 841844, 2005.

Watson, E., Wark, D., and Thomas, J.: Crystallization thermometers for zircon and rutile, Contrib. Mineral. Petr., 151, 413-433, https://doi.org/10.1007/s00410-006-0068-5, 2006.

Wawryk, C. M. and Foden, J. D.: Iron-isotope systematics from the Batu Hijau $\mathrm{Cu}-\mathrm{Au}$ deposit, Sumbawa, Indonesia, Chem. Geol., 466, 159-172, https://doi.org/10.1016/j.chemgeo.2017.06.004, 2017.
Weis, P., Driesner, T., and Heinrich, C. A.: Porphyry-copper ore shells form at stable pressure-temperature fronts within dynamic fluid plumes, Science, 338, 1613-1616, https://doi.org/10.1126/science.1225009, 2012.

Wendt, I. and Carl, C.: The statistical distribution of the mean squared weighted deviation, Chem. Geol., 86, 275-285, 1991.

Wilkinson, J. J.: Triggers for the formation of porphyry ore deposits in magmatic arcs, Nat. Geosci., 6, 917-925, https://doi.org/10.1038/ngeo1940, 2013.

Wotzlaw, J.-F., Schaltegger, U., Frick, D. A., Dungan, M. A., Gerdes, A., and Günther, D.: Tracking the evolution of largevolume silicic magma reservoirs from assembly to supereruption, Geology, 41, 867-870, https://doi.org/10.1130/g34366.1, 2013.

Wotzlaw, J.-F., Buret, Y., Large, S. J., Szymanowski, D., and von Quadt, A.: ID-TIMS U-Pb geochronology at the $0.1 \%$ level using $10^{13} \Omega$ resistors and simultaneous $\mathrm{U}$ and ${ }^{18} \mathrm{O} /{ }^{16} \mathrm{O}$ isotope ratio determination for accurate $\mathrm{UO}_{2}$ interference correction, J. Anal. Atom. Spectrom., 32, 579-586, 2017.

Zwyer, T.: Temporal and Spatial Evolution of Hydrothermal, OreRelated Fluids in the Batu Hijau Porphyry Copper-Gold Deposit, Sumbawa (Indonesia), MSc ETH, Institute of Petrology and Geochemistry, ETH Zurich, 52 pp., 2011. 